\title{
Evaluation of Numeracy Skills of Adults According to the Results of PIAAC 2015 in Turkey
}

\author{
Ramazan Atasoy ${ }^{1, *} \&$ Nezahat Güçlü ${ }^{2}$ \\ ${ }^{1}$ Turkish Ministry of National Education, Turkey \\ ${ }^{2}$ Faculty of Education, Department of Educational Sciences, Division of Educational Administration, Gazi \\ University, Ankara, Turkey \\ *Correspondence: Turkish Ministry of National Education, Turkey. E-mail: atasoyramazan@gmail.com
}

Received: February 15, 2020

Accepted: March 28, $2020 \quad$ Online Published: April 3, 2020

doi:10.5430/wje.v10n2p27

URL: https://doi.org/10.5430/wje.v10n2p27

\begin{abstract}
In this research, it is aimed to put forward the variables that predict the numeracy skills in PIAAC of Turkey, to reveal the relationship between the numeracy skills with educational level, education level of parents, number of books in the household, and annual income. It is also aimed to evaluate the quality of educational outcomes of the Turkish National Education System (TNES). The research is designed in a descriptive-analytical method. The sampling of the study is 5199 households. Mean, t-test, correlation, and CHAID analysis were used in the analysis. In the study, the performance of the numeracy skills of adults in Turkey was found to be very low and, it was emphasized the quality problems of TNES have remained. Moreover, the most powerful predictor of numeracy skills is educational level. There is also a significant relationship between numeracy scores with education level, education level of parents, income, number of books, and computer use. It is expected to provide a new perspective to the policymakers and researchers in education about the appearance of the TNES.
\end{abstract}

Keywords: PIAAC, numeracy skills, quality of education, CHAID analysis

\section{Introduction}

\subsection{Introduce the Problem}

Rapid changes in information technologies and globalization have accelerated the transition to information society from agricultural and industrial society. This transition in paradigm has affected all layers of the community (Toffler, 1981), especially educational systems (Drucker, 1994; Hoy \& Miskel, 2010). Therefore, it has become a vital necessity for individuals and educational institutes to change and transform rapidly and flexibly to survive against the pressures of change from the environment (Özdemir, 2013). Societal, economic and policy pressures on education increase day by day to get ready adults for a complex and technologized community (Hoogland, Díez-Palomar, \& Vliegenthart, 2018). In this new paradigm, one of the educational systems influenced is TNES according to international assessments like PISA and TIMSS (UNESCO, 2017). To overcome the quality problems in education, the Ministry of National Education (MoNE) in Turkey cares about the skills to meet and to develop the expectations from educational institutions that will guide education policies.

Developed and developing countries have become increasingly interested in assessing the skills of adults to monitor how well they are prepared to meet the challenges of the information age. OECD that performed much multi-dimensional and international research has noticed that the global economy demands lifelong learning in the context of economic changing, differentiated business forms and the need for qualified skills. One of these evaluations highlighted skills is Programme for the International Assessment of Adult Competencies (PIAAC). The aim of PIAAC is to help participants countries to get a better understanding of how educational and training systems can promote skills. PIAAC focuses on three basic processing skills: literacy, numeracy and problem solving in technology rich environments. Besides providing a direct measurement of key cognitive skills gained in formal education, PIAAC contributes to present a detailed table of the human capital stock to policymakers in many countries. It is known that qualified educational systems give outputs with higher in numeracy, literacy, and problem-solving skills. The easiest way to keep up with this transformation is to focus on skills, especially on 
numeracy skills.

Numeracy skill - one of these basic processing skills - is considered as an important educational tool about the value added to the country's economy in these digital changes. In this point, numeracy skills play a key role in shaping the future of societies in the digitalizing world. It has been seen also that numeracy skills have also a higher effect on the development and growth of their countries. In this context, Banks and Oldfield (2007) revelead strong positive relationship between numeracy and wealth in a sample of older adults. Estrada-Mejia, De Vries, \& Zeelenberg, (2016) found also a statistically robust and significant correlation between numeracy and wealth, using a cross-sectional and a longitudinal study for a sample of approximately 1,000 Dutch adults. They suggest that on average a one-point increase in the numeracy score is associated with 5 percent more personal wealth. Conversely, low levels of numeracy negatively impact adults wealth and their well-being. Numeracy skills of adults are extremely important for all countries desired to be on the higher ranks of the global value scale (Grotlüschen et al., 2019; OECD, 2017a; Reder \& Bynner, 2008). Further, numeracy skills of adults are not only more likely to be jobless, but also are related to the essential for high school and post-secondary education which is important for re-training, and for upgrading of skills as industries evolve (Coulombe, Tremblay, \& Marchand, 2004; Marr \& Hagston, 2007) in many areas.

The economy and employment-oriented policies have raised the expectations for developing the numeracy skills of all countries. In a knowledge society, the demand for highly qualified professionals is growing. In parallel with the developments of the ongoing digitalization and of the working, education and employment has been subject to constant change (OECD, 2017a). According to the changes and challenges of the work place, the polarization of employment increase in the context of numeracy practices. This event means the danger of unemployment for adults low qualifications and skills. Especially from the beginning of 2000's it is submitted that the level of association of educational institutes with labor markets has reached to a lower level that qualified labor forces couldn't be trained in the context of market needs, therefore regulation on education-employment should become a necessity (Brown \& Lauder, 2006). From this perspective, numeracy performance in Turkey in the global value chain is very important in terms of showing the propensity to innovation and high-tech products. Identifying variables that affect numeracy skills may include the potential to contribute positively to quality improvement processes in education.

Previous research demonstrate that attained education level, sustainable quality of education and gained qualifications of adults are important to support the necessity for matching educational and employment markets. It is also underlined that based on the gained educational qualifications transition from education to business life is possible with the development of skills (OECD, 2007; Murray, Kirsch, \& Jenkins, 1998). This situation has obliged a series of changing in educational policies. Accordingly, the competency and function ability of educational organizations for training information society has become questionable. Depending to increasing in non-routine tasks and decreasing in manual routine tasks, it is expected that there will be more demand for knowledge-based work. This huge change could means that will be affect all educational systems and will be require new educational approaches, training policy in the future, adapting numeracy, literacy and problem solving skills (Hirsch-Kreinsen, 2016; Spitz-Oener, 2006). In this context, the PIAAC, which sets out the OECD's skills-oriented adult competences, is seen as an attempt to contribute to the understanding of the human capital power of Turkey and the challenges of future business and life. One of the skills should be developed at educational institutes is numeracy skills.

\subsection{Numeracy Skills}

This research is focused on the numeracy skills of adults aged $16-65$ years old in Turkey. Numeracy is a term having multiple meanings across a country in an international context. Lack of an accepted term and/or diversity in the conceptualization could misunderstand among researchers and policymakers. However, numeracy is defined as the ability to understand and use numerical information (Peters, 2012). Taking all the consideration with PIAAC consortium members, the numeracy skills are defined (OECD, 2016a) as "the capacity to access, use, apply, interpret, and communicate mathematical information and organize mathematical ideas to effectively manage mathematical conditions in grown-up life responding to the mathematical demands of diverse situations in the information age." According to this definition, numeracy skills are deemed as an ability to the skill for solving the problems of situations in texts, managing by answering the mathematical contents, information's and opinions, which have given in various forms. In other words, it is acknowledged as skills to reach use and interpreted the mathematical knowledge and opinions to manage the situation related to the mathematics' that an individual might encounter in his life (OECD, 2016a). Numeracy skills are also the ability to solve various types of quantitative problems including the apprehension of the arithmetical processes, proportions and probabilistic ideas, understanding of numerical, geometric and graphical types, and quantitative information, critical interpretation of statistical or mathematical messages. 
Wedege (2010) emphasized that numeracy integrated into the workplace and concealed into the digital technology plays an important role in digitisation processes. Globally, depending lack of the necessary numeracy competencies, many adults are disadvantaged and are faced employment challenges in relation to social well-being (Palomar, Hoogland, \& Geiger, 2019). In recent years, the importance of numeracy skills has increased due to the skills that workplaces expect from adults. It is also important that countries have information about the school's outcomes related to numeracy skills, to evaluate and to plan school-based and lifelong learning opportunities. Considering the rapid changes and transformations on the skills required by everyday life, taking a picture of the general aspect of adult numeracy skills is seen as a priority policy area for all countries in the aspect of the development of sustainable policies in education. With this aspect, PIAAC can provide to reach highly qualified data for measuring skills of adults to the participant countries.

\subsection{PIAAC}

PIAAC that performed by OECD is large-scale research that directly assesses the cognitive skills and workplace skills which are required for the success of global economies of the 21 st century is a subsequent part of the PISA project of OECD. It is defined as an international program, which intended to form the present framework of countries for having more skilled labor in the 21 st century and overcome the faced difficulties in this matter. PIAAC adult skills research finds out the extent of the new skills which are required and possessed by the information society and the extent of transferring these skills to daily and business life (OECD, 2013a). PIAAC mainly assesses the interest, attitude, and familiarity to utilize socio-cultural means, skills for using digital technology and communication media, accessing and managing the information integration and evaluation of knowledge, forming new information and communication with others. PIAAC is the first international assessment that collects information on utilizing key business skills of participants at work. It also provides information for whether the skills of adults are complying with the requirement of their work life and whether they have autonomy in the basic aspects of their work.

There are two basic purposes of PIAAC's main implementation assessment. The first one is to provide detailed data for basic skills, which are the subject of PIAAC research. The other purpose is to create an infrastructure to examine changes over time with subsequent PIAAC applications or similar assessment tools. PIAAC is designed to create a link with the previous international assessment of skills of adults too. It also allows countries the opportunity to provide a wide range of data and comparisons in terms of showing the change and development of education systems over time, especially in assessing the effectiveness of the existing education system. It presents important data to countries and policymakers for showing the levels for possessing basic cognitive skills and generic work skills by monitoring their progressing and supporting the new skills which are developed in the life circle.

PISA evaluates which students learn better in a group of 15 years old; in which teachers and schools have more influence on learning. Contrary to this, PIAAC emphasizes which featured adults develop their skills, how they use and gain these skills both in daily and professional life (OECD, 2013a)At this point, it is needed for high-level qualified assessments for basic skills of adult where the countries have economic problems as protecting competitive capacity (Schleicher, 2008).

The results of the researches for the many countries, which were participated in the first and second round of PIAAC, manifested that individuals are not able to use the numeracy skills gained during formal education in daily life and professional environment in older ages (45+) in great scale (OECD, 2013a). Moreover, Marr and Hagston, (2007) state that numeracy skills as used in the workplace are not often similar than what is traditionally taught in school numeracy skills, but also carry on different forms depending on the specific work context, based on many findings. However, numeracy skills play a leading role in paving the way for innovation and technological developments. PIAAC has importance for manifesting the numeracy of adults provided formal, informal and non-formal education. At this point, TNES needs to assess the development of numeracy skills for a quality-oriented sustainable education.

It can be seen that awareness of adult numeracy skills and the factors likely to influence these levels is increased steadily all over the world. Nevertheless, a limited number of studies have been found in the literature (Anders, et al., 2012; Brunello, 2017; Gustafsson, 2016; Heisig \& Solga, 2015; Meroni, Vera-Toscano, \& Costa, 2015) specifically focused on PIAAC numeracy skills. However, unlike OECD arguments based on educational policy approaches, St. Clair (2016) states that there is little evidence related to the PIAAC framing of literacy, numeracy, and problem-solving in technology rich environments has been influential in policy, or that the findings have made a difference. Despite increased interest in the training of adults in the scope of Lifelong Learning in Turkey, it can be seen that studies related to the topic are still fewer (Bumin, 2009; Duman, 2007; Kaya, 2010; Kurt, 2008; Okçabol, 2006; Yildiz, 2004). When the research on this topic is examined, it is seen that the research in this area was 
performed for determining the situation from the quantitative perspective. However, there are no studies directly related to the variables affecting the numeracy skills and the adaptation of knowledge, transfer professional and life skills to daily and professional life in Turkey. Moreover, there are also no studies on the quality of the outputs of the TNES. Wedege (2010) states that PIAAC results have consequences for political decisions concerning the education system. At this point, there is a need for a broad and holistic viewpoint on the variables affects the numeracy performance of the adults; in which level of the education that was received can reveal the distance on the way to become an information society. The quality of education that was received is another concerned aspect. It is expected that this research could give clues in the context of quality and sustainability of education that is given by TNES implicitly in this respect. Therefore, it has been attempted to obtain clues about the quality of education of TNES comparing with PIAAC 2015 adult skills of Turkey's performance and OECD average and some lowest and the highest-performing countries. The second dimension of the study is purposed for a examination of some predictors, which could have an influence on numeracy skills scores of adults in the scope of PIAAC 2015.

This study is also a first in the aspect focusing on the visualization of the CHAID (Chi-squared Automatic Interaction Detection) decision tree analysis, which allows dividing the variables that affect most of adult numeracy skills gradually into subgroups. It should be approved that evaluating the impact of an attempt such as PIAAC on a field such as education and making predictions about the country's education system based on the numeracy skills performance is a hard and deeply political endeavor. It is supposed that it can give a general opinion about the outputs of the educational system to policymakers and directors of education. In this study, it is expected to see the acquisition of the numeracy skills of adults in Turkey from school to daily life and to the transition working life what to be associated with. It is also expected that it could guide the human capital to policymakers and strategy leaders who are the decision-makers on education. The analysis of the data supporting the education policies and the analysis of the variables that affect the numeracy skills of adults gained in school years can make a significant contribution to the field by CHAID analysis. For this purpose, it is aimed to determine the variables that predict the numeracy skills of adults, to put forward the relationship the numeracy skills with the other variables and the evaluation of the education which given to the adults in the context of the outputs of TNES in this research. The answers to the following questions are researched:

i. How is the distribution of numeracy skills scores (high and low proficiency level, educational attainment, international comparison) of adults in Turkey according to the results of PIAAC 2015?

ii. Does the numeracy scores differ significantly by gender of adults in Turkey according to the results of PIAAC 2015 ?

iii. How is the relationship between numeracy skills of adults in Turkey with educational level, education level of parents, and a number of books in the household, and annual income according to results of the PIAAC 2015?

iv. What are the predictor variables, which influence the PIAAC numeracy skills of adults?

\section{Method}

In this study, the descriptive analytics method is used for data analyses. Descriptive analytics, which is continuity for descriptive research, is a research method that scrutinizes data and information stating the current state in a way that developments, patterns and exceptions become evident, in the form of producing standard reports (Joseph \& Johnson, 2013). Descriptive analytics involves the description of the knowledge patterns, dashboards, scorecards, and data visualization using simple statistical methods (Rehman et al., 2016). It aims to understand the facts by analyzing the reason and mode of realization of the fact with this aspect (Collis \& Hussey, 2013). In analytical research, the researcher tries to explain how or why the fact has happened by the overreaching description of descriptive aspects. In analytical research, the researcher uses facts or information already available, and analyze these to make a critical evaluation of the material (Kothari, 2004). Within analytical research articles, data and other important facts after the information is collected and evaluated are used to support an idea evaluating. Using critical thinking skills, the researcher can pull out effectively small details to form greater assumptions about the material. This research has been modeled as shown in Figure 1. 


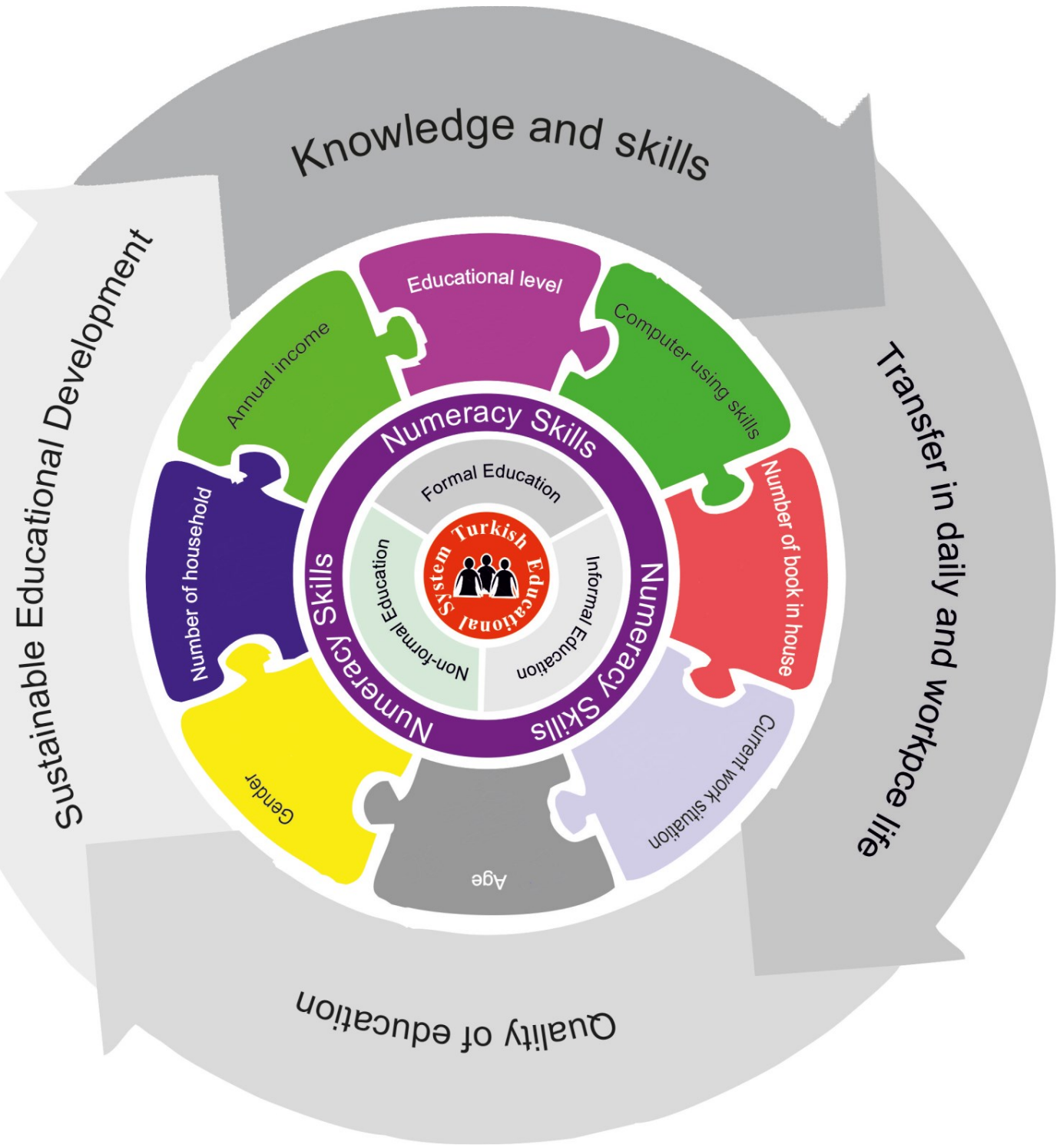

Figure 1. Numeracy Skills Model

\subsection{Sampling}

Sampling is specified with stratified random by the international consortium standards (The PIAAC Technical Standards and Guidelines) [TSG], (OECD, 2014). The consortium allowed each country to choose national sample designs and probabilities of selection sample design according to the TSG. In the main study, sampling selection methods of Turkey consists of three stages according to the PIAAC standard sample design in TSG. In the first stage, systematic PPS (number of households) from a sorted list were selected (from 30 provinces following Turkey Nomenclature of Territorial Units for Statistics [NTUS Turkey]). In the second stage, systematic random from a sorted list (dwelling units), and in the last stage, SRS of 1 person per household were selected via a pre-assigned selection grid, combining stratification sample units into homogeneous groups (OECD, 2014). Due to difficulties in selecting nonresponse and ineligibility rates, all participated countries were encouraged by the Consortium to consider selecting a reserve sample of $10 \%$ or more of the size of the main sample (12.284 DUs; 8847 persons; 5199 target number of completes). According to the TSG standard 4.1.2, the noncoverage rate for all countries, combined over all stages of sampling, may not exceed 5\%. The target population of Turkey consists of all noninstitutionalized adults between age 16 and 65 residing in the country at the time of the main study. The target population excludes adults in institutional collective dwelling units (prisons, hospitals, nursing homes, military barracks military bases, adults who have hearing impairment, blindness/visual or physical disability and adults that were included in the frame but in practice were impossible to be interviewed, adults who move into vacant dwelling units after the 
dwelling lists were constructed and before data collection ends). Parallel to exclusion standards, the sampling frames for Turkey were provided to include $98 \%$ and all exclusions were reviewed by the Consortium. In the main study, according to the TGS, 5,000 of the targeted completes were expected for the sample size and, has reached 5199 full facts number in Turkey.

\subsection{Data Collecting Tools and Data Collection}

Assessment tests and background questionnaires are used as data collection tools in PIAAC adult skills research. Experts in charge at the National Office of Ministry of Labor and Social Security (LSS) translated household background questionnaire and assessment tests developed by OECD. The country coordinator of the PIAAC adult skills survey was conducted by the Ministry of Labor and Social Security. The Turkish Ministry of National Education (MoNE) provided support to LSS assigning 14 teachers for the project.

A laptop computer performed assessment tests with an assistant of Business and Profession Counsellor (BPC) based on computer-based assessment. BPC sampling can make the application with a chosen person in an appropriate time and place. BPC samplings have gone to a chosen address and recorded every household between 16-65 age groups. Depending on the computer using the experience of the participant, all of the surveys and the assessment tests were performed on a laptop or by pen/paper.

The background questionnaire was administered in a computer-assisted personal interview (CAPI) format by the interviewer. Respondents with no experience (or extremely limited experience) about the use of computers were given a pencil-and-paper version of the literacy and numeracy components of the assessment. Respondents took the assessment in a house or in a location that the interviewer agreed. Respondents were free to complete the test. Background questionnaire consists of the educational status, employment status, job, used skills at work and home, income status, literacy, numeracy, problem-solving skills that are used in both daily, work life, and social skills of adults. However, interviewers were trained to encourage respondents.

Depending on the computer experience, respondents are directed to the test assessments. A household who directed to numeracy skills or literacy skills completes the application by reading component, which is valid for everyone. For the individuals who are inadequate for literacy or numeracy skills or having difficulty for reading and writing, the application was ended with an only reading component test. PIAAC test design has been demonstrated in Figure 2 .

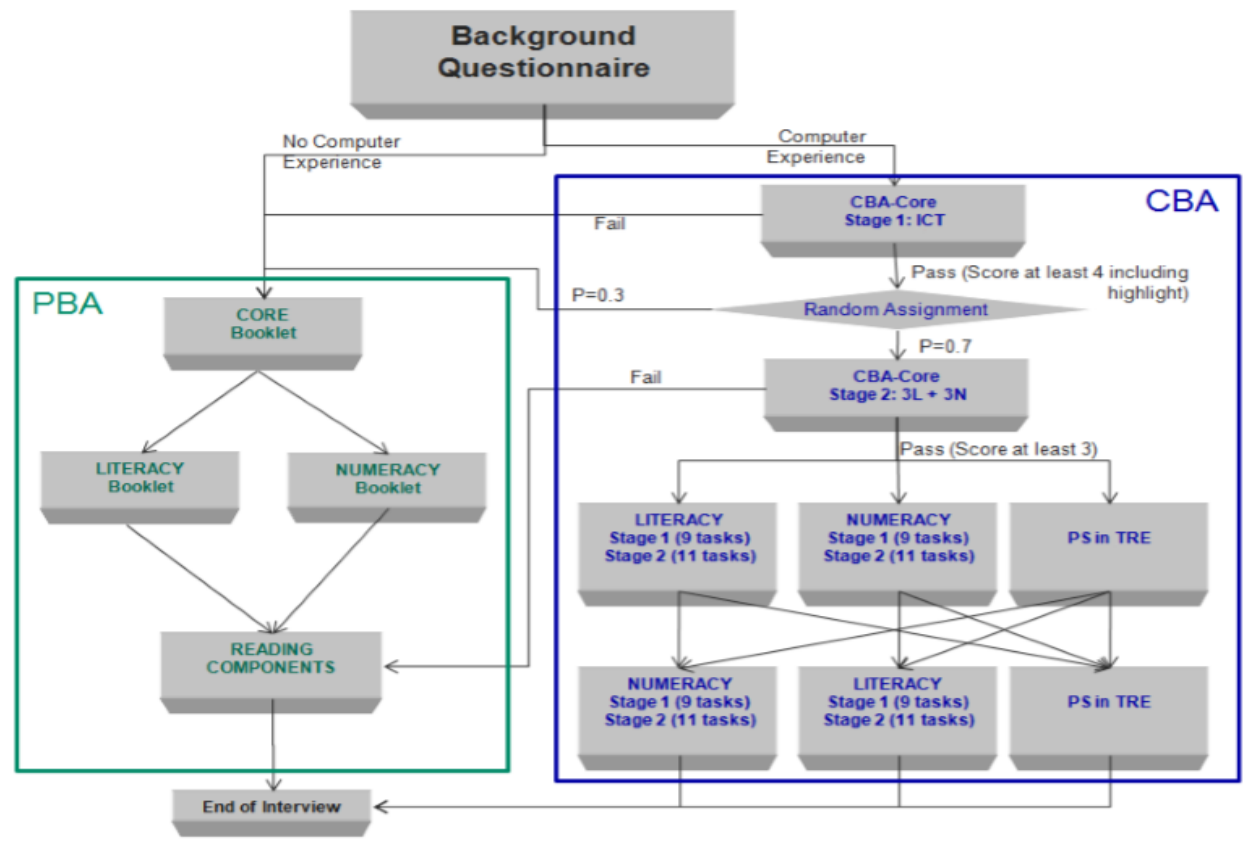

Figure 2. PIAAC Test Design (OECD, 2014)

PIAAC assessment validity and reliability test results are described in the technical analysis PIAAC OECD guidelines. The OECD technical report (2016) demonstrates that reliability and validity have good measurement properties across the countries. According to the reliability studies and quality-assurance, two independent scorers 
checked the equivalence of assessment scoring. For the Turkey sample, reliability for the score from the numeracy skills proficiencies scales was reported alpha $=.85$. The measurement characteristics of the numeracy scores also do not vary by gender, age, educational level, and parents' educational status (PARED). This shows that the numeracy scores perform similarly with different groups psychometrically.

During the data collection process, Turkey partially met a reduced requirement on validation and interviewer training stated in the PIAAC TSG. In this context, firstly, The National Centre of Turkey, (LSS) sent an introductory letter to households in advance of the interviewer visit, study brochure, email and supported respondent helpline to use a variety of tools to increase the visibility and legitimacy of the study. Turkey made strongly to each respondent/household initial contacts in person and to make at least four subsequent contact attempts. For the main study, 293 Interviewers (job and vocational counseling), [JVCs] were assigned. 592 cases were monitored and validation cases were selected randomly. The validity of the study was checked by 1350 phone calls from the department of the National Centre with the participants. Furthermore, the expert support (supervisor) provided technical support to JVCs collecting data in the field. The accuracy of the data was checked by looking for the participants in which the JVCs interviewed (completed, not completed, not communicated, rejected and not required the sampling criteria). In Turkey, 18 to 24 interviewers were assigned to each supervisor. In Turkey, some of the most common reasons for refusal information collected by interviewers on nonresponse cases during the main study were reported to lack of interest, to lack of time and don't want to do exercise.

PIAAC assessment can be completed one hour to two and a half hours depending on the cognitive skills and the education level of the participant household. Participants could complete the reading component tests earlier without completing literacy and numeracy skills tests depending on educational level and using computer competency. Moreover, the duration of the test can change depending on the answers of the household to answers to background survey.

PIAAC has been planned as an ongoing program of adult skills assessment. The first cycle of the assessment has involved three "rounds". The first occurred throughout January 2008 and October 2013; the second took place between January 2012 and June 2016. A third-round involving five additional countries began at the start of 2015 and will extend to June 2019. The second cycle of the assessment is expected to take place over 2018-2023. Turkey participated in the second round. Data collection started on May 6, 2014, and completed on 31 January 2015 in Turkey (OECD, 2016b).

Table 1. Competency Definitions for Numeracy Skills Levels

\begin{tabular}{|c|c|c|}
\hline Levels & Scores & Competency definitions for numeracy skills levels \\
\hline Lower than 1 & $0-175$ & $\begin{array}{l}\text { This level requires performing some basic operations as counting money, gradation, and } \\
\text { basic arithmetic operations or recognition of common expressions. }\end{array}$ \\
\hline Level 1 & $176-225$ & $\begin{array}{l}\text { Tasks in this level require carrying out single steps or simple processes in a concrete } \\
\text { context, which have clear mathematical content. These tasks usually require carrying } \\
\text { out single steps or simple processes like counting, gradation, making basic arithmetic } \\
\text { operations. }\end{array}$ \\
\hline Level 2 & $226-275$ & $\begin{array}{l}\text { Tasks in this level require carrying out two or more steps and processes as calculation } \\
\text { with integers and common decimal numbers, percentages and fractions, simple } \\
\text { measuring and spatial expressions, interpreting the simple data and statistics' in texts } \\
\text { and tables. }\end{array}$ \\
\hline Level 3 & $276-325$ & $\begin{array}{l}\text { Tasks in this level require a sense of number and space, recognition of verbal or numeric } \\
\text { expression of mathematical relationships, patterns and rates, interpreting of data in } \\
\text { texts, tables, and graphics. }\end{array}$ \\
\hline Level 4 & $326-375$ & $\begin{array}{l}\text { Tasks in this level require analyses of statistics and probability; analysis on spatial } \\
\text { relations and changings, on rates and formulas and understanding of more complicated } \\
\text { processes of reasoning. }\end{array}$ \\
\hline Level 5 & $376-500$ & $\begin{array}{l}\text { Participants should integrate mathematical information in different kinds, make an } \\
\text { inference, developing mathematical arguments or model sort work with them, } \\
\text { reasoning, assessing and make critical thinking. }\end{array}$ \\
\hline
\end{tabular}

Source: OECD, (2016a). Skills matter: Further results from the survey of adult skills. 
To measure the skills of adults, and to facilitate the interpretation of the scores assigned to respondents, PIAAC includes tasks that range from very easy to very challenging from 0 to 500 . Each scale is divided into proficiency levels. Adults expected to answer at least half of the items at that level correctly. The competency definition given in Table 1 were placed for interpreting skill levels.

\subsection{Data Analysis}

In the study, to give an overview of the numeracy skills of adults in Turkey and selected countries, arithmetic means, standard deviation and scatter plot diagram are used. For arithmetic means, the numeracy performance of the adults in Turkey was analyzed with the highest performing country (Japan) and the lowest-performing country (Chile) and the OECD average in the PIAAC 2015. Scatter plot diagram and radar graphic allowing the visual display of the distribution of Turkey's numeracy skills is accomplished via interactive PIAAC Data Explorer (PDX). Furthermore, to test the differences between the male and female groups t-test; and to determine the relationships between the numeracy skills with educational level, education level of parents, number of books in the household, and annual income, Pearson correlation analysis was used. CHAID analysis was performed for determining the numeracy scores of predictive variables of adults in Turkey.

Before starting the data analysis, it was checked whether the data to be used in the research meets the assumptions of missing data and extreme values. In this context, the missing values (74) were excluded from the analysis and no extreme values (0) were found. For Pearson's correlation and independent t-test analyses, three important assumptions (linearity, equal variance or, alternatively, as the assumption of homoscedasticity and normality) about the population must hold true (Huck, 1974). Preliminary, the linearity, equal variance, normality, and multicollinearity assumptions were checked at a scatter diagram of the sample data to make sure no violation of the assumptions. The examination of the scatter plots provided further information on linearity. The scatter plot diagram of the sample data shows no evidence of a curvilinear relationship. It can be said a good reason to suspect that the population is not characterized by a curvilinearity, heteroscedasticity, or non-normality. The data used in the study were also performed for the distribution of normality and the variation coefficients of the data were justified in the acceptable range (18-25\%). However, the normality assumption according to the test statistics of the Kolmogorov-Smirnov were not justified. Besides, it is recommended that all methods mentioned above should be evaluated together with the assumption of the normal distribution (Stevens, 2012). At this point, the skewness and kurtosis values were performed. The skewness and kurtosis values were found to be between \pm 1 limits. Tabachnick and Fidell (2013) consider the skewness and kurtosis values to be within \pm 1.5 limits for normal distribution. In addition to this, when the linear regression analysis results of numeracy scores and educational status, age group, computer experience, number of books at house, parents educational status (PARED), immigrant status and gender variables were examined for each variable, the VIF values $(1.25-1.65)$ were in the range. The CI values were between 3.80 and 18 and the tolerance values (690-799) were quite high. It was observed that multicollinearity linkage assumptions were met for the independent variables. Hence, it was found that the data were normally distributed and suitable for analyzing parametric tests. On the other hand, since the nature of CHAID analysis does not require the assumptions of parametric tests, the variables were analyzed directly.

CHAID analysis which was developed by Kass (1980) is one of a decision tree technique (Albayrak, Koltan, \& Yllmaz, 2009) that is constructed by splitting subsets of the space into two or more child nodes repeatedly, beginning with the entire data set. CHAID analysis is an important statistical approach, which examines dependent variables with independent variables in a homogenous structure into subgroups (Koyuncugil \& Özgülbaş, 2008; Maimon \& Rokach, 2008).

The CHAID analysis generates rules for the classification of a dataset and uses a tree-shaped structure to represent sets of decisions. When the dividing process meets with stopping rules dividing process is stopped. The procedure aims to divide a series of objects according to determined criteria by significantly differentiated subgroups (Magidson, 1994). To find the best split at any node, any allowable pair of categories of the predictor variables are merged until there is no statistically significant difference within the pair for the target variable (Magidson, 1994). The merging step also calculates the adjusted p-value by applying Bonferroni adjustments (Doğan \& Özdamar, 2003). Statistical test in CHAID analysis changes depending on the aimed variable (dependent variable) as that if the target variable (dependent variable) is continuous as it is in F; if the target variable is categorical, it is chi-square $(\chi 2)$.

Decision trees as in CHAID analysis provide very useful and practical solutions for many classification problems. Decision trees are accepted as a useful interfering model for forming understanding visible models because of the structure of the tree and supremacy for interpretation (Koyuncugil \& Özgülbaş, 2008). A diagram of the tree was formed by choosing the most important relationships (Hoare, 2004). It is accepted as a method, which one does not 
consider the hypothesis of regression; however, analysis has similar results with regression analyses (Kayri, Elkonca, Şevgin, \& Ceyhan, 2014). CHAID analysis is also preferred because continuous and categorical data can be included at the same time and can be used in large samples and potentially very reliable estimates.

The weighted average of 10 plausible values (PVs) was calculated using the IDB Analyzer program and Interactive Data Explorer for the numeracy skills performance of the selected countries. As different sets of items were administered to different respondents in PIAAC it is used the weighted posteriori variance estimating for each country depending on the country-specific proficiency distributions for each cognitive domain. The weighted posteriori variance is computed (expected error variance/total variance) using all PVs through the population modeling (Efron, 1982). In this study, analyses calculated using the IDB analyzer and Interactive Data Explorer were performed on weighted plausible values1-10. On the other hand, SPSS 23 package program for CHAID analysis, were also used to analyze the data.

\section{Findings}

Average scores related to performance for PIAAC 2015 adult numeracy skills are presented in Table 2.

Table 2. PIAAC Average Scores for Numeracy Skills and Percentages of Competency

\begin{tabular}{|c|c|c|c|c|c|c|c|c|}
\hline \multirow[b]{2}{*}{ Numeracy } & \multicolumn{2}{|c|}{ Turkey } & \multicolumn{2}{|c|}{ OECD } & \multicolumn{2}{|c|}{ Japan } & \multicolumn{2}{|c|}{ Chile } \\
\hline & $\overline{\mathrm{X}}$ & $\mathrm{sd}^{*}$ & $\bar{X}$ & $\mathrm{sd}^{*}$ & $\overline{\mathrm{X}}$ & $\mathrm{sd}^{*}$ & $\overline{\mathrm{X}}$ & $\mathrm{sd}^{*}$ \\
\hline Mean $(\overline{\mathbf{X}})$ & 219.4 & 1.4 & 263.0 & 0.2 & 288.2 & 0.7 & 206.1 & 3.1 \\
\hline Below L1*(\%) & 20.2 & 0.9 & 6.7 & 0.1 & 1.2 & 0.2 & 30.8 & 1.6 \\
\hline $\mathbf{L} 1 * *(\%)$ & 30.0 & 1.3 & 16.0 & 0.1 & 7.0 & 0.5 & 31.2 & 7.0 \\
\hline $\mathbf{L} 2 * *(\%)$ & 33.3 & 1.6 & 33.0 & 0.2 & 28.1 & 0.8 & 25.9 & 1.5 \\
\hline $\mathrm{L3}^{* *}(\%)$ & 13.0 & 0.8 & 31.8 & 0.2 & 43.7 & 0.8 & 10.0 & 1.2 \\
\hline $\mathbf{L} 4 * *(\%)$ & 1.4 & 0.3 & 10.2 & 0.1 & 17.3 & 0.7 & 1.8 & 0.5 \\
\hline $\mathbf{L} 5 * *(\%)$ & $\mathrm{c}^{*}$ & $\mathrm{c}^{*}$ & 1.0 & 0.0 & 1.5 & 0.2 & $\mathrm{c}^{* *}$ & $\mathrm{c}^{* *}$ \\
\hline
\end{tabular}

*Plausible value 1-10 weighted means with 80 replications is based on. sd*: Standart deviation. **Below L1: Competency below level 1; **L1: Competency Level 1;**L2: Competency Level 2;**L3: Competency Level 3; **L4: Competency Level 4; **L5: Competency Level 5; ${ }^{* *}$ : not available.

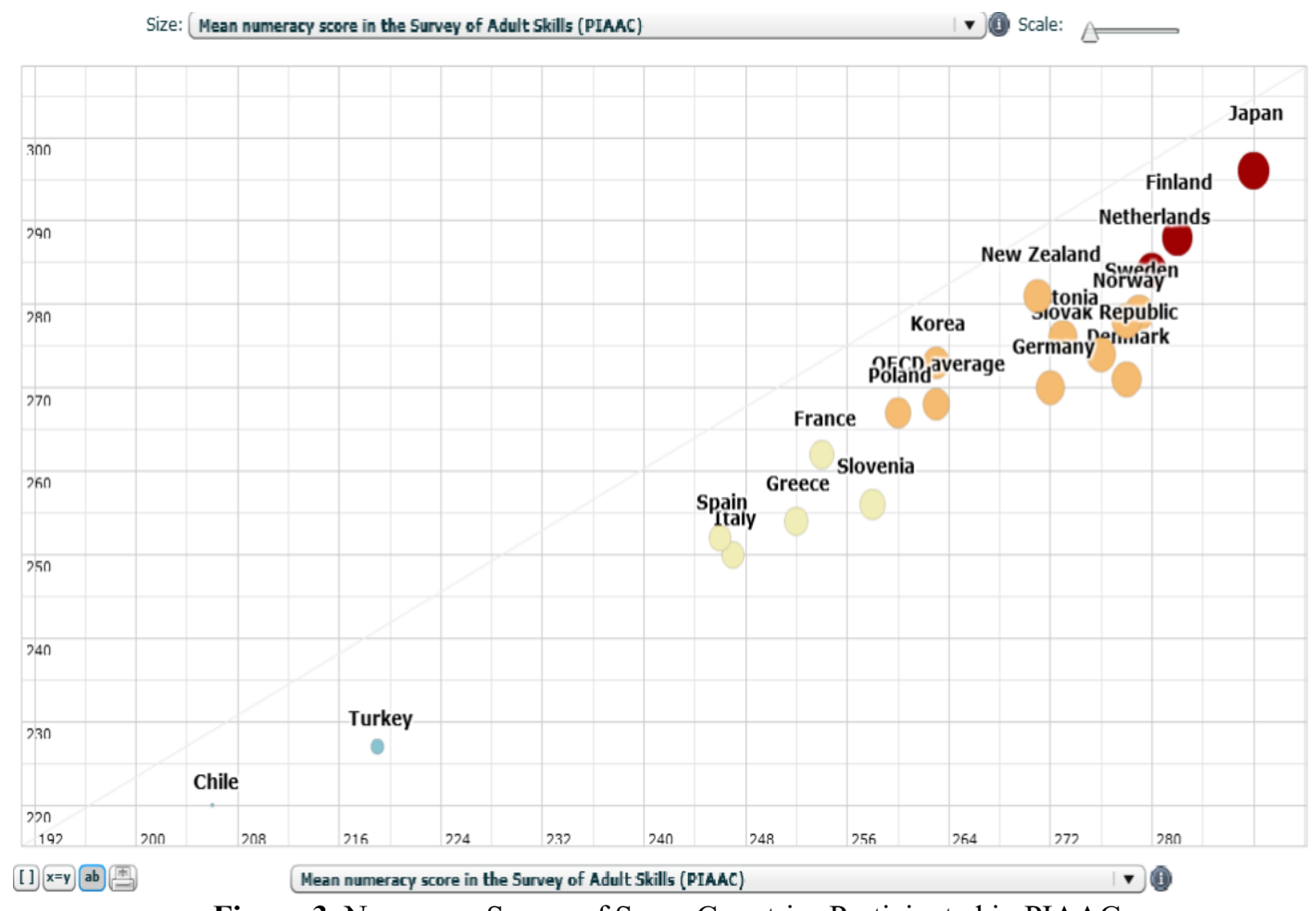

Figure 3. Numeracy Scores of Some Countries Participated in PIAAC

Source: It is prepared with the OECD website by using the interactive data forming screen. 
Adults in Turkey show significantly below-average proficiency in numeracy domain assessed among the OECD countries that took part in the survey. The mean numeracy score $(\bar{X}=219.4)$ is approximately more than 43 points lower than the OECD average $(\bar{X}=263.0)$ in Turkey. This means that the average numeracy proficiency of adults in Turkey is the upper end of Level 1, the lower end of Level 2 and one proficiency level lower than the international average. This means also that the large proportions of adults in Turkey have poor numeracy skills. As many as 50.2\% of adults in Turkey attain only Level 1 or below in numeracy (OECD average of 22.7\%) On the other hand, Table 2 shows that a small proportion of adults in Turkey has high numeracy. Proficiency in numeracy of Level 4 or Level 5 means significantly lower than the OECD average of 10.6\%. In Figure 3, Turkey's performance between the OECD participating countries is provided visually.

Comparison scores of numeracy of Turkey PIAAC adult skills with the other countries have shown in the scatter plot in Figure 3. The radar graphic in Figure 4 shows, adult numeracy performance in Turkey decomposes markedly from those of other participating countries together with adults in Chile.

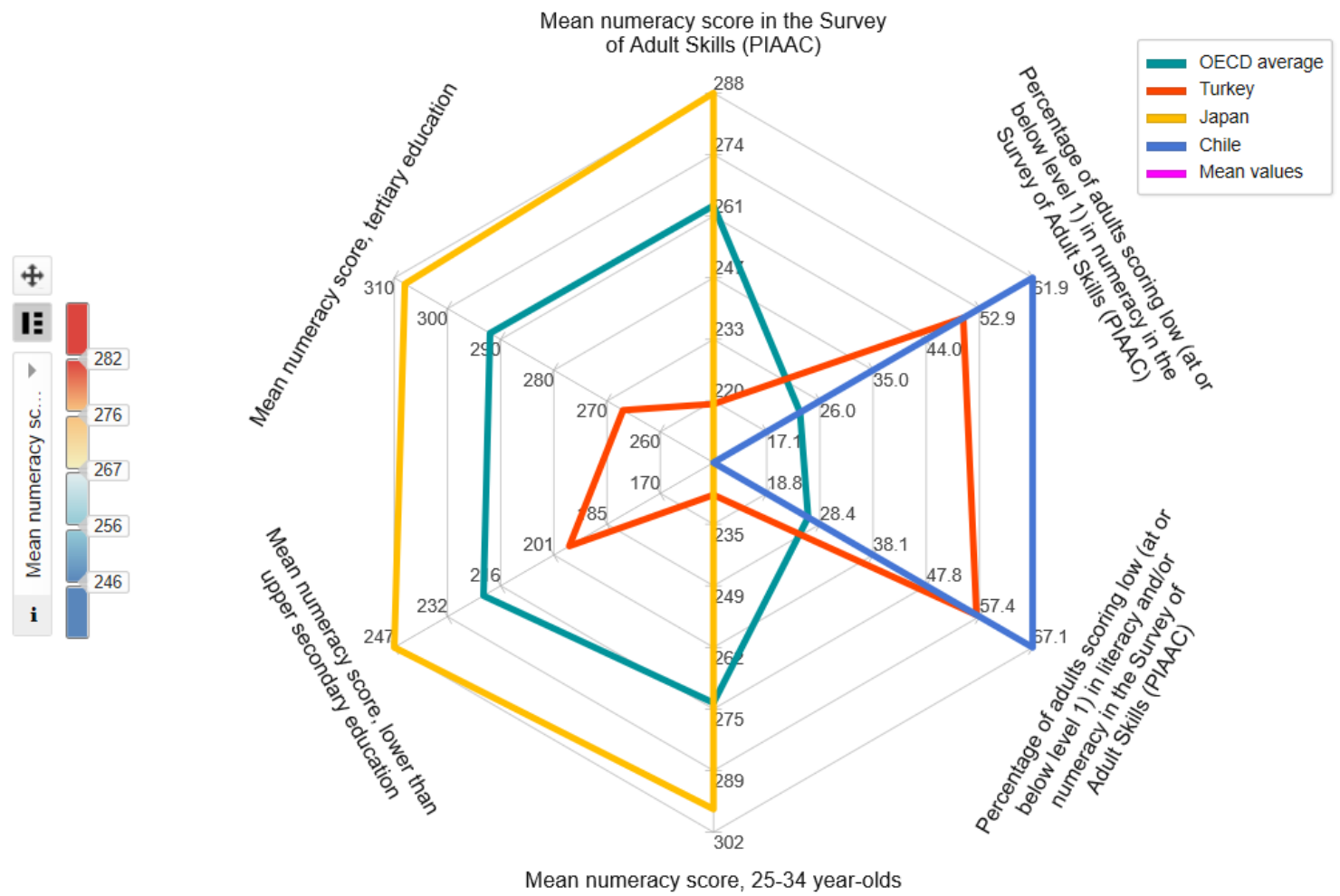

Figure 4. Numeracy Skills of Some Countries That Participated in PIAAC

Source: OECD website by using interactive data screen.

In Figure 4, this decomposition can be seen in the percentage of adults scoring low (at or below Level 1) as in the numeracy score averages. However, it is seen that also in access to the upper levels of proficiency (at Level 4 or Level 5) lagged far behind the OECD average of adults in Turkey. On the other hand, the numeracy scores of the adult 25-34 age group in Turkey has been reached very low. Similarly, mean numeracy scores of lower and upper secondary education and tertiary education have been found low too according to the other participating country. Whether a significant difference in numeracy scores of adults in Turkey, who have participated in the PIAAC 2015 with gender variable is determined with t-test. 
Table 3. T-Test for Gender Variables of PIAAC Numeracy Skills Scores

\begin{tabular}{|c|c|c|c|c|c|c|}
\hline \multirow{3}{*}{ Variable } & \multirow{2}{*}{\multicolumn{2}{|c|}{$\begin{array}{c}\text { Male } \\
\mathbf{N}=\mathbf{2 6 2 7}\end{array}$}} & \multirow{2}{*}{\multicolumn{2}{|c|}{$\begin{array}{l}\text { Female } \\
\mathrm{N}=2567\end{array}$}} & \multirow[b]{3}{*}{$\mathbf{t}$} & \multirow[b]{3}{*}{$\mathbf{p}$} \\
\hline & & & & & & \\
\hline & $\overline{\mathrm{X}}$ & $\mathrm{sd}$ & $\overline{\mathrm{X}}$ & sd & & \\
\hline Numeracy & 232.60 & 49.41 & 205.72 & 59.16 & 17.79 & $.01 \%$ \\
\hline
\end{tabular}

*Significant difference level: 0.05; Analyses were performed on weighted plausible values 1-10 via the IDB Analyzer Programme and calculated manually according to the t-test formula.

When the Table 3 is examined, t-test found that numeracy performance of the adults of male $(\bar{X}=232.60$, ss $=$ 49.41) were significantly higher than those of female adults $(\bar{X}=205.72$, ss $=59.16)$, $[\mathrm{t}(5192)=17.79, \mathrm{p}<.01]$ (two-tailed) according to PIAAC 2015 results. In this study, it is questioned whether there is any relationship between numeracy skills of adults in Turkey with educational level, age group, education level of parents, number of books in the household, computer use, and annual income according to results of PIAAC 2015.

Table 4. PIAAC 2015, Relationship between Numerical Skills and Educational Level, Education Level of Parents, Number of Books in the Household and Annual Income

\begin{tabular}{|c|c|c|c|c|c|}
\hline Variables & 1 & 2 & 3 & 4 & 5 \\
\hline 1. Educational level & 1 & & & & \\
\hline 2. PARED $* *$ & $0.38^{*}$ & 1 & & & \\
\hline 3. Book in house & $0.42 *$ & $0.49 *$ & 1 & & \\
\hline 4.Annual income $e^{* * *}$ & $0.41^{*}$ & $0.18^{*}$ & $0.19 *$ & 1 & \\
\hline 5. Numeracy skills & $0.42 *$ & $0.22 *$ & $0.28 *$ & $0.29 *$ & 1 \\
\hline
\end{tabular}

*Correlation is significant at the .001 level (2-tailed). Analyses were performed on weighted plausible values $1-10$ via the IDB Analyzer programme. **PARED: Educational level of parents. This item concerning the education information derived from original or coded BQ items. "What is the highest education level your mother obtained?" (question 15), and (2) "What is the highest education level your father obtained?". The information is grouped under three categories using the classification of ISCED (1997): (1) Lower secondary education or less (ISCED 0, 1 and 2), (2), Upper secondary education (ISCED 3), and (3) Tertiary education (ISCED 4 and 5). *** Annual income: Earnings variables (continuous, continuous purchasing power parity (PPP) corrected, deciles) for BQ earnings items.

The relationship between PIAAC 2015 numeracy skills and education level of adults, age, educational status of parents, number of books at home and annual income status are given in Table 4 . According to this, there is a medium level significant relationship in positive direction between educational level with numeracy scores $(\mathrm{r}=.42 ; \mathrm{p}$ $<.001)$; lower level in positive direction significant relationship between annual net income with numeracy scores ( $\mathrm{r}$ $=.29 ; \mathrm{p}<.001)$. There is also lower level in positive direction significant relationship between number of books of household $(\mathrm{r}=.28 ; \mathrm{p}<.001)$; and lower level in positive way between educational level of parents (PARED) with numeracy scores $(\mathrm{r}=.22 ; \mathrm{p}<.001)$. In addition to this, there are a medium level significant relationship in positive direction between number of books of household with numeracy scores $(\mathrm{r}=.28 ; \mathrm{p}<.001)$; annual net income with educational level $(\mathrm{r}=.41 ; \mathrm{p}<.001)$; and educational level of parents $(\mathrm{r}=.38 ; \mathrm{p}<.001)$.

Related to the fourth sub-problem of the research CHAID analysis have performed to determine the variables that predict and explain the success of numeracy. According to the result of CHAID analysis, it was found 25 nodes that explain the performance of the numeracy. 


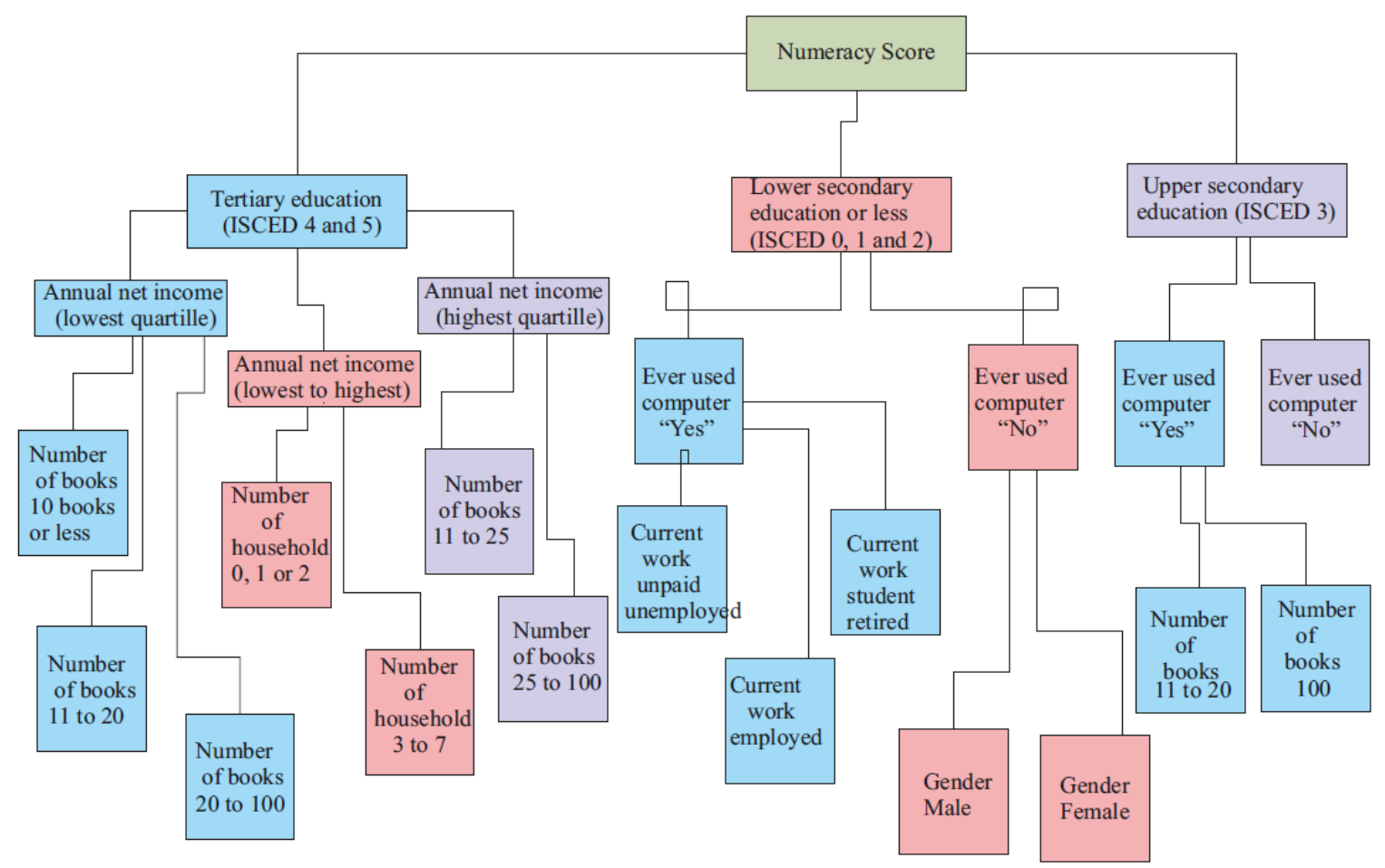

Figure 5. All Childs and Nodes That Predict the Numeracy Skills

As it can be seen on Figure 6 the best expository beginning node for numeracy scores is found as "educational level" (highest level of schooling) variable $[\mathrm{F}(2,5191)=807.20 ; \mathrm{p}<.05]$. Adults who have under-graduate and graduate degree are accumulated on node 1 ( $\mathrm{X}=264.77 ; \% 18.5 ; \mathrm{n}$ : 962 ).

Adults have graduation from "lower secondary or less" educational status (ISCED 2, lower secondary; ISCED 0 and 1 , primary education or less) are placed on node 2 ( $X=201.42 ; \% 57.5 ; n: 2989)$. Adults who have graduation from "high school or vocational high school" are accumulated on node 3 ( $X=245.31 ; \% 23.9 ; n$ : 1243). These findings manifest that as increasing the educational level, skills of numeracy increase.

The secondary sub-variance which explains the average score of numeracy of adults "under-graduate and post-graduate" (above high school) is determined as annual net income $[\mathrm{F}(2,959)=14.50 ; \mathrm{p}<.05]$. Adults whose education level bachelor and above who stated that the annual net income is as low as "the lowest quintile and missing are given on node $4(\overline{\mathrm{X}}=257.82 ; \% 8.9 ; \mathrm{n}$ : 462). Adults who stated that annual net income is closer to "the lowest quintile and to the highest level" are accumulated at node 5 ( $\bar{X}=266.47 ; \% 4.5 ; \mathrm{n}: 234)$. It is found that the average numeracy score of adults who stated have "higher" annual net income is also higher than the other groups $(\overline{\mathrm{X}}=275.22 ; \% 5.2 ; \mathrm{n}: 268)$.

The secondary sub-variance which explains average score for numeracy for adults graduated or not graduate primary schools (node 7 and 8) and for adults graduated from high school or vocational high school (node 9 and 10) is "computer using" skills variance $[\mathrm{F}(1,2987)=390.10 ; \mathrm{p}<.05]$ and $[\mathrm{F}(1,1241)=51.04 ; \mathrm{p}<.05]$. Adults graduated or not graduated from primary schools who "use computer" are given at node $7(\bar{X}=221,98 ; \% 24.2 ; n$ : 1258$)$. Adults graduated or not graduated from primary schools who "don't use computer" are accumulated at node $8(\overline{\mathrm{X}}=186$. 48; \%33.3; n: 1731). On the other hand, adults graduated from "high school or vocational high school who use computer" are given at node $9(\overline{\mathrm{X}}=248.03 ; \% 24.2 ; \mathrm{n}: 1258)$. Adults graduated from "high school or vocational high schools who don't use computer" are accumulated at node $10(\overline{\mathrm{X}}=220.37 ; \% 2.3 ; \mathrm{n}: 122)$.

It's determined that 3rd level sub-variance that explains the numeracy scores of adults belong to the category of missing and have at lowest rate of annual income who are graduated or post-graduated as" number of books" of household $[F(2,457)=9.01 ; p<.05]$. Figure 7 shows adults who are in under-graduate and above educational level and whose annual net income is in "the lowest level and in the missing" category. In this group adults who have " 10 and less books at household and missing" are accumulated at node $11(\overline{\mathrm{X}}=247.24 ; \% 2.2 ; \mathrm{n}$ : 116); adults who have "number of books up to 100 " are accumulated at node $12(\overline{\mathrm{X}}=257.915 ; \% 5.1 ; \mathrm{n}: 264)$ and adults who have "number 
of books 26-100+" are accumulated at node $13(\bar{X}=272.88 ; n: 80)$.

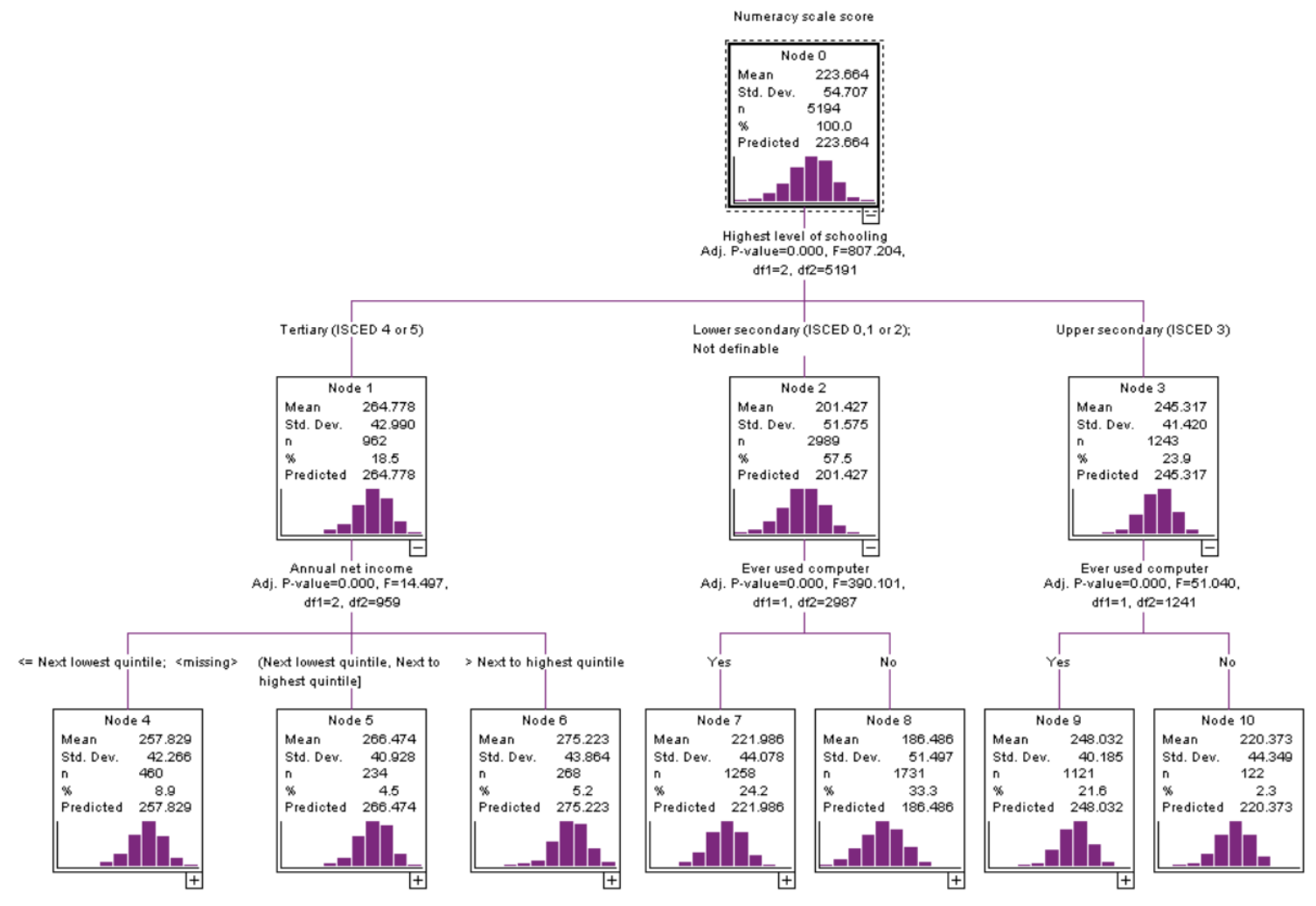

Figure 6. Beginning and Child Nodes that Predict the Numeracy Skills

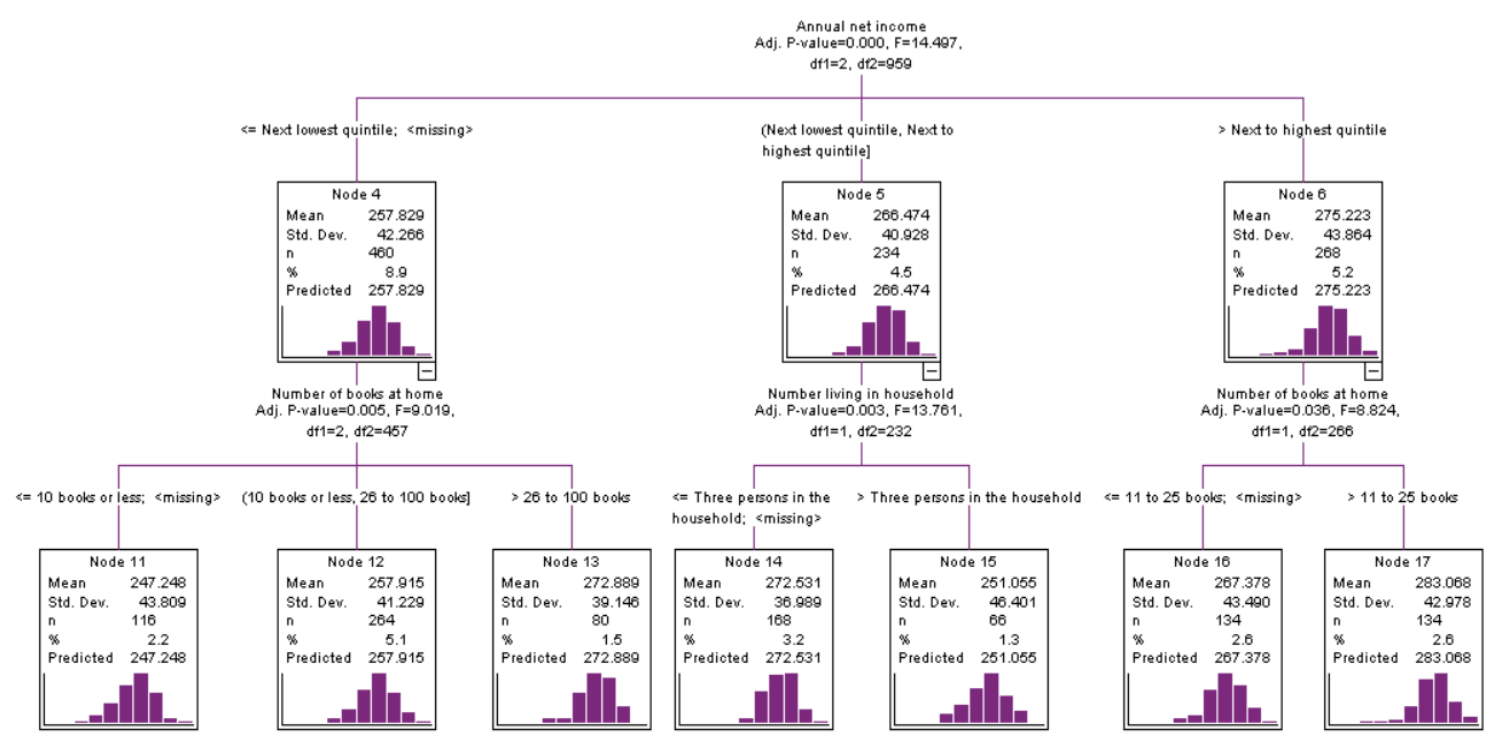

Figure 7. 3rd Level Sub-Nodes for Under-Graduated and Post-Graduated Educational Level

The 3rd sub-variance that explains the score of numeracy skills of adults whom have education at under-graduate and post-graduate level and stated their annual income as both in the lowest part and close to the highest part is determined as "the number of households" $[\mathrm{F}(2,232)=13.76 ; \mathrm{p}<.05]$. In this group, "3 and less than 3 person" of household number is given node $14(\overline{\mathrm{X}}=272.531 ; \% 3.2 ; \mathrm{n}: 168)$, "higher than 3 person" of household is given at node $15(\overline{\mathrm{X}}=251.05 ; \% 1.3 ; \mathrm{n}: 66)$. 
The 3rd level sub-variance that explains the scores of numeracy of adults who under-graduate or post-graduate and have higher income is determined as a "number of books at home" $[\mathrm{F}(2,266)=8.82 ; \mathrm{p}<.05]$. Those who have "maximum 11-25 books" at home are given at node $16(\overline{\mathrm{X}}=267.37$; \%2.6; n: 134); those who have "more than 25 books" at home are given at node $17(\overline{\mathrm{X}}=283.06 ; \% 2.6 ; \mathrm{n}$ : 134).

It is determined that $3 r d$ sub-variance is actual employing status $[\mathrm{F}(2,1255)=26.18 ; \mathrm{p}<.05]$ explains the score for numeracy skills of adults who have graduated from primary school or lower educational level and can use a computer in figure 8 .

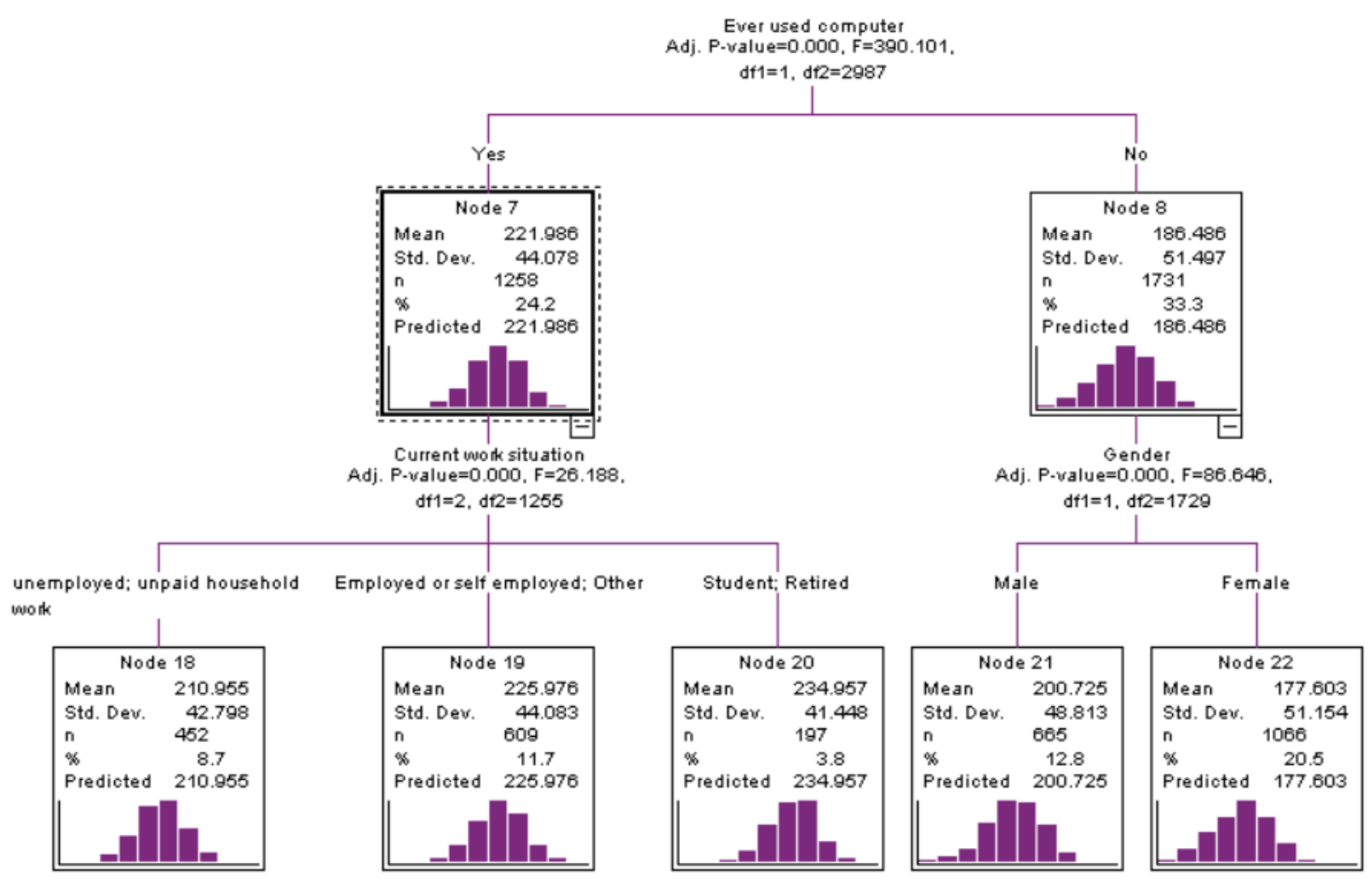

Figure 8. 3rd Level Sub-Variances for Primary Schools and Lower Educational Level

"Unemployed, actively seeking job and working at homework's unpaid" are accumulated at node $18(\overline{\mathrm{X}}=$ 210.95; \%8.7; n: 452); "employed and those who are in the category of the others" are accumulated at node $17(\overline{\mathrm{X}}=$ 225.97; \%11.7; n: 134) and adults who are "student and retired" are accumulated at node $20(\overline{\mathrm{X}}=234.95 ; \% 3.8 ; \mathrm{n}$ : 197).

On the other hand, the 3rd level sub-variance explains the score of numeracy of adults who have a primary and lower educational level and cannot use a computer is determined as "gender" $[\mathrm{F}(1,1729)=86.64 ; \mathrm{p}<.05]$. In this group, category of "male" are accumulated at node $21(\overline{\mathrm{X}}=200.72 ; \% 12.8 ; \mathrm{n}: 665)$; category of "female" are accumulated at node $22(\overline{\mathrm{X}}=177.60 ; \% 20.5 ; \mathrm{n}: 1066)$.

Adults who graduated from high schools and can use computer who have number of books "up to 10 " at their home are accumulated at node $23(\overline{\mathrm{X}}=240.72 ; \% 7.1 ; \mathrm{n}: 371)$; "up to 100 books" at their home are accumulated at node 24 $(\overline{\mathrm{X}}=249.07 ; \% 12.0 ; \mathrm{n}: 621)$ and " $26-100$ " book at their home are accumulated at node $25(\overline{\mathrm{X}}=264.07 ; \% 2.5 ; \mathrm{n}$ : 129). 3rd level sub-nodes for scores of numeracy for high school educational level are given below figure 9 . 3rd level sub-variance explains scores of numeracy of adults who graduated from high school and can use a computer is determined the number of books at home $[\mathrm{F}(2,1118)=17.002 ; \mathrm{p}<.05]$. 


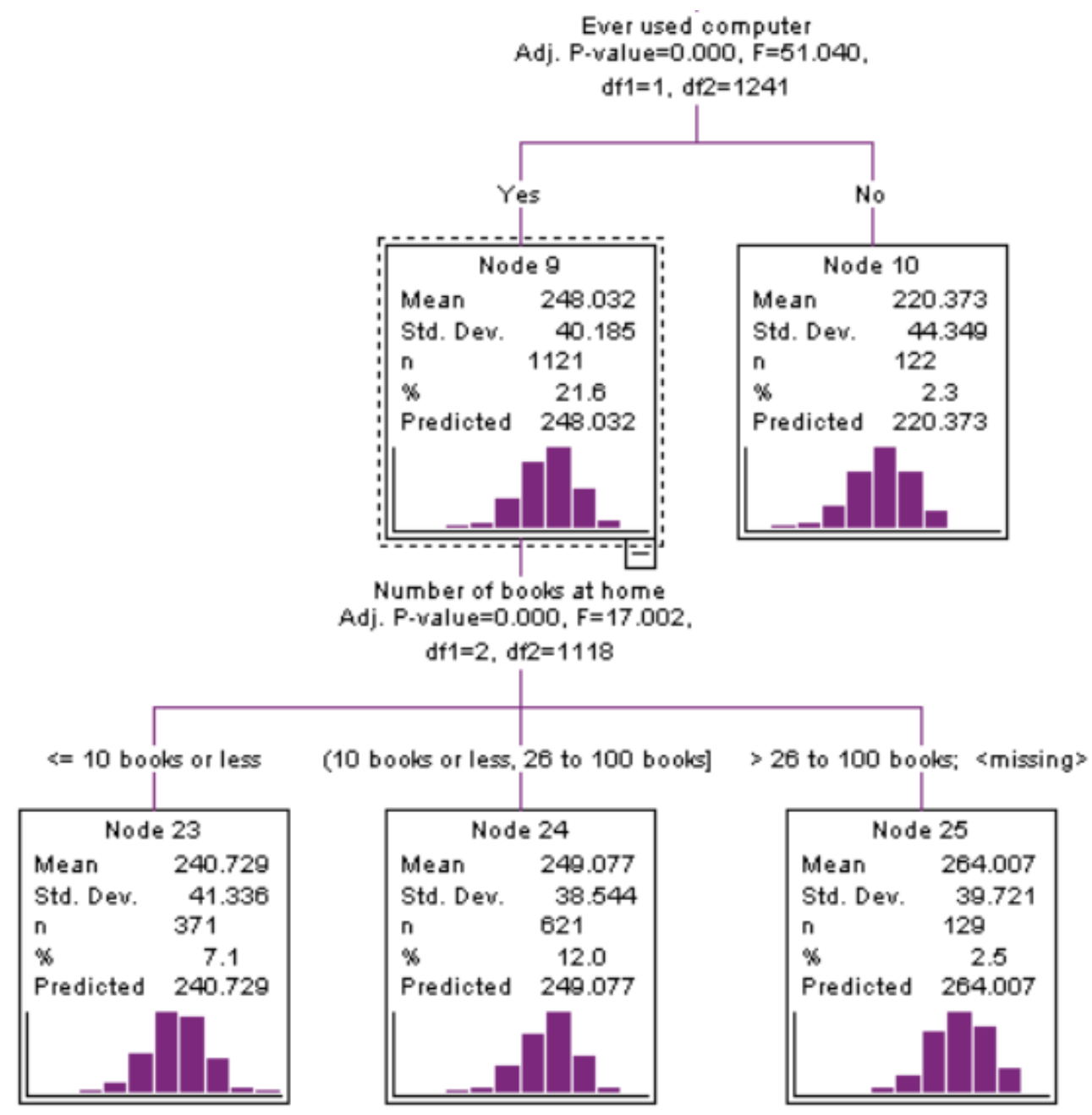

Figure 9. 3rd Level Sub-Nodes for Scores of Numeracy for High School Educational Level

\section{Discussion and Conclusion}

A function of providing skills to adults is a primary duty of school systems. Therefore, it needs to assess the factors, which affect the adults' skills in the context of the educational system and the framework of the scope of quality in education. In this study, numeracy skills scores of selected countries (Chile, Turkey, Japan, and OECD average) of PIAAC 2015 are given primarily. It is seen that numeracy scores of Turkey in PIAAC are at the upper zone of level 1 and just under level 2 for competency performance according to the classification of competency levels. When the performance of the adults is examined according to all of the competency levels, it is found that performance for numeracy of adults who are both in level 1 and under the level 1 is almost more than half of all of the participants. In other words, scores of numeracy in Turkey are very low. Turkey has a better performance just than Chile and has a lower degree than the OECD average score. This means that a majority of adults show no or only basic proficiency in numeracy skills in Turkey. Adult numeracy performance in Turkey decomposes markedly from those of other participating countries together with adults in Chile. This divergence is due to the low level of stacking and the difficulty in accessing high-level skills. It is stated that PISA and PIAAC scores of Turkey are low in all three areas, rate of both students and adults have shown lower performance is increased; nevertheless no one reached to 5th competency level in the reports of ERG (2017), MEB (2016a), OECD (2010) and TEDMEM (2016a). Similarly, Polat (2014) and TEDMEM (2016a) stated that the result of adult skills are low and informed the finding that results have parallelism with PISA results in their reports. This low performance at the level of competency can be interpreted as a sign of the quality problems of TNES outputs at the formal schools' organization and the difficulties related to the transfer of skills provided. It can be interpreted as a reflection of the relatively low levels of educational 
attainment among adults in Turkey. This is thought to be associated with the educational attainment status of the selected sample design. Thus, compared with adults in the other participating OECD countries such as Japan (OECD, 2014 b), this low average proficiency in numeracy of the adults in Turkey who are nearly $80 \%$ of $55-65$ year-olds and over $50 \%$ of 25-34 year-olds could be explained with have no complete upper secondary education (MEB, 2018).

It is concluded that there is a significant difference in favor of male adults at numeracy skills according to gender. Gender differences are a crucial ingredient for any policy. Recent analyses (OECD, 2014; OECD, 2015) which usually focus at the secondary school level show the persistence of gender inequalities in the acquisition of the different competencies. PISA 2015 assessment indicates that males tend to outperform females in numeracy. According to Spelke (2005), the gender gap in numeracy does not exist between the ages of 4 and 10 . However, it starts to come out as children finish primary school (Beilstein and Wilson, 2000), in the transition from childhood to teenage years. As mentioned by Machin and Pekkarinen (2008) in most countries, the skill distribution of 15-years old boys is more dispersed than that of their girls equivalent. While there is not any significant difference in the literacy of mathematics of 15 years old students, literacy of science scores has shown a significant difference in favor of female students from 2006 to 2015 according to the PISA 2015 preliminary report (MEB, 2016a). On the other hand, it is determined that scores of literacy of science are in favor of male students at low-level competency. It is observed that there is a significant difference in favor of female students for the scores of mathematics and science (numeracy) and verbal-mathematics (equal weight) fields for the scores according to the gender in the undergraduate placement exam (LYS) results (OSYM, 2017). This can be commented as one of the positive results of policies directed to the schooling of female students. It is also supported by the problem-16 -solving

PIAAC 2015 survey that there is a significant difference in favor of male adults who are both in advanced ages and having education levels at primary school or lower level. One of the reasons why numeracy skills performance is in favor of male adults can be said to be due to the fact that the last level of education reaches was in favor of men (Maya, 2013). In this context, Yaşar (2018) states that the gender stereotypes, psychosocial traits, cultural aspects and the decisions of females concerning their workplace and daily life could be playing a key role in state female low-achievement in numeracy.

Findings related to the third sub research question have revealed a significant relationship at a medium level in the positive direction between the educational level of adults and their numeracy performance. As the level of education reached, as in many countries, there is a parallel increase in numeracy skill scores. Considering the contribution of numeracy skills performance to individual and country development, it can help to explain the link between the level of education achieved and the innovation and development of countries. Gebremeskel, Simuchimba, \& Mulenga, (2019) emphase similar suggestion that the number of professional employees, training, and absence of skill gap have a positive impact on innovation performance. In TNES, more than half of the participants in the secondary, primary or less education level and on the other hand, master and doctorate education level very low could be considered to be an important indicator in terms of demonstrating the numeracy performance and explaining the competitiveness of human capital.

There is also a low-level relationship in the positive direction between the educational level of parents (PARED) and the number of books at home with numeracy scores. This study is revealed that parents' education seems to have an impact on adults' numeracy proficiency. In a similar way, it is determined in the study of Özer and An1l (2011) and in the study of Anders et al., (2012) which examines the variables affect the numeracy skills that educational level of parents and number of books at home have the influence on the success of science and mathematics. A linear relationship has determined too between the numbers of books at home for 4th and 8th classroom levels with success of the student in the national reports of TIMSS 2011 and TIMSS 2015 (MEB, 2016b). Karabay (2013), and Karabay, Y1ldırım and Güler (2015) have precipitated in the research which aimed to determine the variables related to mathematics literacy scores of students who have participated in PISA 2003, 2006 and 2009 applications that there is a relationship between PISA mathematical literacy with the educational level of parents and numbers of books at home. Similarly, İzci (2011) has found that the anxiety of children for learning decreased by increasing the level of their parents and they have become more open to learning. Also, in the study of Yıldırım, Hacıhasanoğlu, Karakurt, and Türkleş (2011) which factors influenced the problem-solving skills of students of the high school were examined, the finding that educational level of parents has a relationship with problem-solving skills of students supports the findings which are emerged from PIAAC adult skills. The variable of PARED status using both international assessments, (PISA and PIAAC) is related to the absolute mobility (Oloomi, 2020). It can be said that PIAAC numeracy scores demonstrate that growing up in a disadvantaged family where the parents have low levels of education often affect the proficiency of the adults in Turkey concerning absolute mobility. 
There is a significant relationship in the positive direction between annual net incomes with numeracy scores. The relationship between individual earning and cognitive skills (numeracy, literacy, and problem-solving in technology rich environments) that is seen to have explanatory power on earnings above and beyond years of schooling is emphasized in recent studies. The finding of Hanushek, Schwerdt, and Wiederhold (2015) that adults have higher cognitive skills also have higher income according to the PIAAC 2012 results in the 23 countries, which participated in the first cycle, also supports this result. However, there are also studies showing that non-cognitive skills should be taken into consideration (Anghel and Balart, 2017; Hedengren and Stratmann, 2012; Hitt et al., 2016). This situation is thought to require cognitive and non-cognitive multidimensional research in understanding the pattern between education and income.

The results related to the fourth sub-problem of the research are concerned for the determining of the variables that influence the PIAAC numeracy skills of adults. It is determined that the educational level of the adults as the initial variant is the best predictor of the success of numeracy. According to the results of PIAAC 2015 Turkey adults' skills, it can be said that basic processing skills increase in parallel with increasing the educational level of adults reached. It is specified that the finding as educational attainment was a true predictor of knowledge procession skills, which is a no striking and expected result in OECD (2016a) "Skills are important" report. Storen (2016) similarly stated that human capital with a higher educational level was one of the main factors of innovativeness and person who have university degrees shown more creativity.

It is seen that sub-variances explained the scores of numeracy skills of adults who undergraduate and post-graduate in the next sub-node are respectively related with annual net income and number of households. In other words, it is observed increasing on their income by increasing of skills of numeracy and increasing of the number of the household has caused decreasing the success by inversely proportional. In the study, which researched the variances that affect the success of students, Gelbal (2010) determined that OBBS scores of students decrease by increasing the number of siblings and decreasing the educational level of the mother. Also, a number of books at household variance are placed in the variances that influence the basic processing skills of adults to have primary and secondary education levels. Number of books of the household is a variable that deals in all of the international benchmarks. This finding has similarity with the results of Anders, et al., (2012), Çeçen (2015), Erbaş (2005), Karabay (2013) Karabay, Yıldırım and Güler (2015), Özer (2009), Reder and Bynner (2008), Şaşmazel (2006) and Yiğit (2013). In this context findings of the assessment of PISA, and TIMSS (MEB, 2016b) also support the PIAAC results. On the other hand, it is determined that the adults who have graduation and post-graduation degree stated have lower income and less number of book in their household have shown performance on the high school level. It is also recorded that scores for basic processing skills of adults in secondary education level who have less number of book in their households have a downward trend to the level of primary education and lower level in similarly.

The other variance explains the numeracy scores of adults whose educational levels are in primary school and lower and high school level is using computer and communication technologies. Many studies on computer use support this result (Akçay, Aydoğdu, Yıldırım, \& Şensoy, 2005). Tezoh (2015) also determined that the variance of using ICT at home is the second important predictor variable after the socio-economic and socio-cultural variances in $65 \%$ of 37 countries. It is thought that students using a computer are more successful for the internalization of processing knowledge. This finding can be interpreted as computer using is a important indicator for explaining numeracy scores. In addition to this, the use of the computer was also associated with 'current job status' which explains the score of numeracy of adults who have an educational level primary school and lower level. Adults who belonged to the category of 'Unemployed or not working' are ones who have the lowest scores for numeracy. Reder (2015) gives place to the opinion that technological skills are related with more actively participated in social conclusions and success at the workplace. Likewise, Hanushek, Schwerdt, and Wiederhold (2015) and Reder and Bynner (2008) have reported a significant relationship in the aspects of statistic and economic between skills and level of wage in some countries which have participated in the PIAAC survey. On the other hand, gender variance has come forth for the explanation of scores of numeracy of the adults who have education level on primary school and lower level and give a negative response to the computer using question. Female adults in this category have the lowest score of numeracy. It is thought that this dissociation which is disadvantageous for women in the group of adults who have educated at a low level is derived from access to education and some taboo in the social structure.

This study analyzes the variables that affect the numeracy skills of adults in Turkey but also reveals continuing problems of skills training in TNES. Education offered in educational institutions in Turkey remains at the level of knowledge and understanding. The PIAAC results manifest that Turkish educational output is depriving of analyzing, synthesis, commenting and evaluating skills, which are defined as high-level cognitive skills by Bloom. It is seen that there is a sharp fall in the overall average of Turkey for fields of Science and Mathematics literacy and a 
regression to the beginning point of the PISA journey in the report of MEB (2016a). Similarly, it is seen that student rates at 1 st level and under the 1st level were very close to the average scores of OECD in 2012, this rate has increased to the former point in PISA 2015 and risen to the low-level competency level rates in PISA 2006. On the other hand, students rate which at the high-level competency for literacy of science and mathematics is too low that couldn't compare with the other OECD countries, it is seen that student rate which are at the 4th and higher level at PISA 2015 Turkey is much lower than the rate of high-level competency at PISA 2012 Turkey. It is shown that there are examples and questions for 2nd competency level mainly placed in the 5th grade lesson book, conversely, to this, there are not examples for high-level competency in the research which examined the competency levels of success at 8th class books of İskenderoğlu and Baki (2011). This finding is also revealing the scores that emerged in the results of PIAAC and PISA. Failure to demonstrate high-level competency performance means that adults in Turkey just perform single staged simple operations as counting with money, ranking and calculating basic arithmetic operations or recognizing common statements, they can carry out basic mathematical processes in concrete contexts where the mathematical content is clear. It is expected from the adults at this level to combine different kinds of mathematical knowledge, to develop mathematical arguments or models, evaluating and critical thinking on them in the condition required interpretation.

In terms of all indicators variables analyzed in this study, PIAAC numeracy performance of Turkey has reached the conclusion the lowest country after Chile. This low numeracy performance of the adults in Turkey is also seen clearly in international assessments such as PISA and TIMSS. Cemaloğlu (2011) interpret this situation in the context of quality of education and underlines that there is no positive change in the quality of education. As a result, it can be said that the problems influencing the learning of adults carry on. Although TNES has undergone a series of reforms aimed at strengthening the quality of education in the last 20 years, it has not been reflected in the results of international assessments. On the one hand, we are faced with the educational quality problems and its challenges, on the other hand, with the situation where the education is the solution for a sustainable future as stated UNESCO (2005) report. Is education quality in Turkey the problem or the solution toward a sustainable future? At current levels of unsustainable performance according to PISA and PIAAC numeracy results, it could be concluded that education is part of the problem. Regarding the quality in education, Atasoy and Cemaloğlu (2018) emphasized that there are positive progressions for determining the conceptual framework of the quality of education if it is evaluated the quality policies of TNES with systemically approach and holistic view. Nevertheless, the policy-setting and implementation process, which is disconnected from the field, seems difficult to maintain. The quality problems of TNES are thought to limit the transfer of knowledge and skills learned in school environments to daily and business life. The PIAAC 2015 results seem to exacerbate the quality problems in the Turkish National Education System and the debate on sustainable development in education.

\section{Suggestions}

The monitoring of skills development processes of students with low academic performance in formal education institutions should be considered. Besides, the issue of inability to perform at a high level should be focused on. To overcome quality problems in education and to bring the skills that are expected to be gained to individuals in line with the requirements of daily and business life, it is important to develop the school capacity including the participation of students, teachers, parents, school administration and other stakeholders. On the other hand, the functionality of non-formal education institutions and other non-governmental organizations at the point of skill development can be strengthened. At this point, training courses could be reorganized to be skill-oriented and aligned with the requirements of the labor markets. To solve the quality problems in education, it may be useful to address education policies with a holistic perspective and system approach. Besides, it may be beneficial to consider a series of structural changes in the TNES since the 2000s and to review the contribution of quality-oriented policies in education to the education system. In this regard, the awareness can be gained to improve instructional capacity, to promote reading culture, and to increase the use of information technologies in education. Finally, participation in lifelong learning towards developing the existing skills of adults might be encouraged. For future research, the role of lifelong learning practices in providing skills to adults can be explored. In addition, the functionality of formal and non-formal education institutions in providing skills to adults can be investigated.

\section{Acknowledgments}

1. This article was produced from a doctoral dissertation entitled "Evaluation of the International Adult Skills (PIAAC 2015) Study in Terms of the Turkish National Education System". 
2. This article was presented as a declaration on "12th. International Education Management Congress".

Conflicts of Interest: The authors declare no conflict of interest.

\section{Referances}

Akçay, S., Aydoğdu, M., Yıldırım, H., \& Şensoy, Ö. (2005). Fen eğitiminde ilköğretim 6. sınıflarda çiçekli bitkiler konusunun öğretiminde bilgisayar destekli öğretimin öğrenci başarısına etkisi. Kastamonu Eğitim Dergisi, 13(1), 103-117.

Albayrak, A., Koltan, S., \& Yılmaz, Ş. (2009). Veri madenciliği: Karar ağacı algoritmaları ve İMKB verileri üzerine bir uygulama. Süleyman Demirel Üniversitesi İktisadi ve İdari Bilimler Fakültesi Dergisi, 14(1), 31-52.

Anghel, B., \& Balart, P. (2017). Non-cognitive skills and individual earnings: new evidence from PIAAC. SERIEs, 8(4), 417-473. https://doi.org/10.1007/s13209-017-0165-x

Anders, Y., Rossbach, H. G., Weinert, S., Ebert, S., Kuger, S., Lehrl, S., \& Maurice, J. (2012). Home and preschool learning environments and their relations to the development of early numeracy skills. Early Childhood Research Quarterly, 27(2), 231-244. https://doi.org/10.1016/j.ecresq.2011.08.003

Atasoy, R., \& Cemaloğlu, N. (2018). Evaluation of quality policies on education in Turkish education system. Universal Journal of Educational Research, 6(7), 1504-1518. https://doi.org/10.13189/ujer.2018.060711

Banks, J., \& Oldfield, Z. (2007). Understanding pensions: cognitive function, numerical ability and retirement saving. Fiscal Studies, 28, 143-170. https://doi.org/10.1111/j.1475-5890.2007.00052.x

Beilstein, C., \& Wilson, J. (2000). Landmarks in route learning by girls and boys. Perceptual and Motor Skills, 91(3), 877-882. https://doi.org/10.2466/pms.2000.91.3.877

Brown, P., \& Lauder, H. (2006). Globalization, knowledge and the myth of the magnet economy. Globalisation, Societies and Education, 4(1), 25-57. https://doi.org/10.1080/14767720600555046

Brunello, L. R. (2017). The effects of vocational education on adult skills, employment and wages: What can we learn from PIAAC? SERIEs, 8(4), 315-343. https://doi.org/10.1007/s13209-017-0163-z

Bumin, E. (2009). Yetişkin eğitimi programlarını uygulayan eğitimcilerin mesleki formasyonları, mesleğe dönük algl ve ihtiyaçları (Unpublished master thesis). Marmara Üniversitesi Eğitim Bilimleri Enstitüsü, İstanbul.

Cemaloğlu, N. (2011). PISA sonuçları ve MEB müfredatı. Türk Yurdu, 2(4), 31-32.

Collis, J., \& Hussey, R. (2013). Business research: A practical guide for undergraduate and postgraduate students. Palgrave Macmillan.

Coulombe, S., Tremblay, J. F., \& Marchand, S. (2004). Literacy scores, human capital and growth across fourteen OECD countries. Ottawa: Statistics Canada.

Çeçen, Y. (2015). Sosyo kültürel ve sosyo ekonomik değiş̧kenlerin PISA fen okuryazarllğını yordama gücünün yıllara göre değerlendirilmesi, (Unpublished master thesis). İstanbul. İstanbul Aydın Üniversitesi Sosyal Bilimler Enstitüsü.

Doğan, N., \& Özdamar, K. (2003). CHAİD analizi ve aile planlaması ile ilgili bir uygulama. Journal of Medical Sciences, 23(5), 392-397.

Drucker, P. F. (1994). The age of social transformation. Atlanta: Atlantic.

Duman, A. (2007). Yetişkinler eğitimi. Ankara: Ütopya.

Efron, B. (1982). The jackknife, the bootstrap, and other resampling plans. Society of Industrial and Applied Mathematics CBMS-NSF Monographs, 38. https://doi.org/10.1137/1.9781611970319

Erbaş, K. C. (2005). Factors affecting scientific literacy of students in Turkey in programme for international student assessment (PISA), (Unpublished master thesis). Ankara: Orta Doğu Teknik Üniversitesi.

ERG. (2017). Eğitim izleme raporu 2016-2017. İstanbul: Eğitim Reformu Girişimi Eğitim Gözlemevi.

Estrada-Mejia, C., de Vries, M., \& Zeelenberg, M. (2016). Numeracy and wealth. Journal of Economic Psychology, 54, 53-63. https://doi.org/10.1016/j.joep.2016.02.011

Gebremeskel, Y., Simuchimba, B., \& Mulenga, C. (2019). Skills Gap, Innovation, and Firms Performance in Zambia. International Journal of Economics and Finance, 11(8), 129-129. https://doi.org/10.5539/ijef.v11n8p129 
Gelbal, S. (2010). Sekizinci sınıf öğrencilerinin sosyoekonomik özelliklerinin Türkçe başarısı üzerinde etkisi. Eğitim ve Bilim, 33(150), 1-15.

Grotlüschen, A., Buddeberg, K., Redmer, A., Ansen, H., \& Dannath, J. (2019). Vulnerable subgroups and numeracy practices: How poverty, debt, and unemployment relate to everyday numeracy practices. Adult Education Quarterly, 69(4), 251-270. https://doi.org/10.1177/0741713619841132

Gustafsson, J. E. (2016). Lasting effects of quality of schooling: Evidence from PISA and PIAAC. Intelligence, 57, 66-72. https://doi.org/10.1016/j.intell.2016.05.004

Hanushek, E. A., Schwerdt, G., \& Wiederhold, S. (2015). Returns to skills around the world: Evidence from PIAAC. European Economic Review, 73(C), 103-130. https://doi.org/10.1016/j.euroecorev.2014.10.006

Hedengren, D., \& Stratmann, T. (2012). The dog that didn't bark: what item nonresponse shows about cognitive and non-cognitive ability. SSRN working paper No. 2194373. https://doi.org/10.2139/ssrn.2194373

Heisig, J. P., \& Solga, H. (2015). Secondary education systems and the general skills of less-and intermediate-educated adults: A comparison of 18 countries. Sociology of Education, 88(3), 202-225. https://doi.org/10.1177/0038040715588603

Hitt, C., Trivitt, J., \& Cheng, A. (2016). When you say nothing at all: the predictive power of student effort on surveys. Econ Educ Rev, 52, 105-119. https://doi.org/10.1016/j.econedurev.2016.02.001

Hirsch-Kreinsen, H. (2016). Zum Verhältnis von Arbeit und Technik bei Industrie 4.0. Aus Politik und Zeitgeschichte, 66(18-19), 10-17.

Hoare, R. (2004). Using CHAID for classification problems. New Zealand: Wellington.

Hoogland, K., Díez-Palomar, J., \& Maguire, T. (2018). Towards a second cycle of PIAAC. Programme for the International Assessment of Adult Competencies. In D. Dalby, D. Kaye, B. Kelly \& J. Stacey (Eds.), Proceedings of the 25th International Conference on Adults Learning Mathematics (ALM25): Boundaries and Bridges: adults learning mathematics in a fractured world. London, UK.

Hoy, W. K., \& Miskel, C. G. (2010). Eğitim yönetimi. (S. Turan, Trans.) Ankara: Nobel.

Huck, S. W. (1974). Reading statistics and research. New York: Harper \& Row.

İskenderoğlu, T., \& Baki, A. (2011). İlköğretim 8. sınıf matematik ders kitabındaki soruların PISA matematik yeterlik düzeylerine göre sinıflandırılması. Eğitim ve Bilim, 36(161), 287-301.

İzci, E. (2011). Attitudes of the students towards learning attending first level primary state and private schools. Education Sciences, 6(1), 988-1006.

Javier Díez-Palomar, Kees Hoogland \& Vincent Geiger. (2019). Numeracy in adult education: discussing related concepts to enrich the Numeracy Assessment Framework. Eleventh Congress of the European Society for Research in Mathematics Education, Utrecht University, Feb 2019, Utrecht, Netherlands. hal02409259

Joseph, R. C., \& Johnson, N. A. (2013). Big data and transformational government. IT Professional, 15(6), 43-48. https://doi.org/10.1109/MITP.2013.61

Kass, G. (1980). An exploratory technique for investigating large quantities of categorical data. Applied Statistics, 29, 119-127.

Karabay, E. (2013). Aile ve okul özelliklerinin PISA okuma becerileri, matematik ve fen okuryazarllğını yordama gücünün yıllara göre incelenmesi (Unpublished master thesis). Ankara: Gazi Üniversitesi Eğitim Bilimleri Enstitüsü.

Karabay, E., Yıldırım, A., \& Güler, G. (2015). Yıllara göre PISA matematik okuryazarlığının öğrenci ve okul özellikleri ile ilişkisinin aşamalı doğrusal modelleri ile analizi. Mehmet Akif Ersoy Üniversitesi Ĕgitim Fakültesi Dergisi, 1(36), 137-151.

Kaya, E. H. (2010). Avrupa Birliği yaşam boyu ögrrenme ve yetişkin ĕgitimi politikaları (Unpublished doctorate thesis). Ankara: Ankara Üniversitesi Eğitim Bilimleri Enstitüsü.

Kayri, M., Elkonca, F., Şevgin, H., \& Ceyhan, G. (2014). Ortaokul öğrencilerinin fen ve teknoloji dersine yönelik tutumlarının CHAID analizi ile incelenmesi. Eğitim Bilimleri Araştırmaları Dergisi, 4(1), 303-316. https://doi.org/10.12973/jesr.2014.41.15

Kothari, C. R. (2004). Research methodology: Methods and techniques. New Age International. 
Koyuncugil, A. S., \& Özgülbaş, N. (2008). Veri madenciliği: Tıp ve sağlık hizmetlerinde kullanımı ve uygulamaları. International Journal of Informatics Technologies, 2(2), 21-32.

Kurt, İ. (2008). Yetişskin eğitimi. Ankara: Asil.

Machin, S., \& Pekkarinen, T. (2008). Global Sex Differences in Test Score Variability. Science, 322, 1331-1332. https://doi.org/10.1126/science.1162573

Magidson, J. (1994). The chaid approach to segmentation modeling: Chi-squared automatic interaction detection. In R. P. Bagozzi (Ed.), Advanced methods of marketing research (pp. 118-189). Cambridge.

Maimon, O., \& Rokach, L. (2008). Data mining with decision trees: Theory and application. USA: World Scientific. https://doi.org/10.1142/6604

Marr, B., \& Hagston, J. (2007). Thinking beyond numbers: Learning numeracy for the future workplace. Adelaide, South Australia: National Centre for Vocational Education Research (NCVER).

Maya, İ. (2013). Türk Eğitim Sistemindeki Cinsiyet Eşitsizliklerinin AB Ülkeleri İle Karşılaştırılması. Eğitim ve Bilim, 38(168), 69-84.

MEB. (2016a). PISA 2015 ulusal ön raporu. Ankara: Millî Eğitim Bakanlığı, Ölçme, Değerlendirme ve Sınav Hizmetleri Genel Müdürlüğü.

MEB. (2016b). TIMSS 2015 ulusal matematik ve fen bilimleri ön raporu. Ankara: Millî Eğitim Bakanlığı, Ölçme, Değerlendirme ve Sınav Hizmetleri Genel Müdürlüğü.

MEB. (2018). Millî Eğitim İstatistikleri, Örgün Eğitim 2016/2017. Ankara, Milli Eğitim Bakanlığı.

Meroni, E. C., Vera-Toscano, E., \& Costa, P. (2015). Can low skill teachers make good students? Empirical evidence from PIAAC and PISA. Journal of Policy Modeling, 37(2), 308-323. https://doi.org/10.1016/j.jpolmod.2015.02.006

Murray, S., Kirsch, I., \& Jenkins, L. (1998). Adult Literacy in OECD country. Washington, DC: National Center for Education Statistics, U.S. Department of Education, Office of Educational Improvement.

OECD. (2007). Lifelong Learning and Human Capital. Paris: OECD. Retrieved from http://www.oecd.org/dataoecd/43/50/38982210.pdf

OECD. (2013a). The Survey of Adult Skills: Reader's Companion. Paris: OECD. Retrieved from http://dx.doi.org/10.1787/9789264204027-en

OECD. (2014). PIAAC Technical Standards and Guidelines. Paris: OECD. Retrieved from www.oecd.org/site/piaac

OECD. (2014b). Education at a Glance, country note Japan. Paris: OECD. Retrieved from http://www.oecd.org/education/Japan-EAG2014-Country-Note.pdf

OECD. (2015). The ABC of Gender Equality in Education: Aptitude, Behaviour, Confidence. OECD Publishing, Paris. Retrieved from http://dx.doi.org/10.1787/9789264229945-en

OECD. (2016a). OECD Skills Matter: Further Results from the Survey of Adult Skills, OECD Skills Studies. Paris: OECD. Retrieved from http://dx.doi.org/10.1787/9789264258051-en

OECD. (2016b). Survey of Adult Skills Technical Report (2nd ed.). Paris: OECD.

OECD. (2017a). OECD Skills Outlook. Skills and Global Value Chains. Paris: OECD. Retrieved from http://dx.doi.org/10.1787/9789264273351-en

Okçabol, R. (2006). Halk eğitimi (Yetişskin Eğitimi). Ankara: Ütopya.

Oloomi, S. (2020). Parental Education and Skill Indicators of Children: An Intergenerational Mobility Study. Retrieved [2020] from PIAAC Gateway website: [https://static1.squarespace.com]. Washington, DC.

OSYM. (2017). 2017 LYS sınav sonuçlarının açıklanması. Ankara: ÖSYM. Retrieved from https://www.osym.gov.tr

Özdemir, S. (2013). Eğitimde örgütsel yenileşme. Ankara: Pegem.

Özer, Y. (2009). Uluslararası ögrenci değerlendirme programı (PISA) verilerine göre türk ögrrencilerin matematik ve fen bilimleri başarıları ile ilişkili faktörler (Unpublished master thesis). Ankara. Hacettepe Üniversitesi Sosyal Bilimler Enstitüsü.

Özer, Y. (2009). Uluslararası ögrenci değerlendirme programı (PISA) verilerine göre türk öğrencilerin matematik ve fen bilimleri başarıları ile ilişkili faktörler (Unpublished master thesis). Ankara. Hacettepe Üniversitesi Sosyal 
Bilimler Enstitüsü.

Özer, Y., \& Anıl, D. (2011). Öğrencilerin fen ve matematik başarılarını etkileyen faktörlerin yapısal eşitlik modeli ile incelenmesi. Hacettepe Üniversitesi Eğitim Fakültesi Dergisi, 41(41), 313-324.

Palomar, J., Hoogland, K., \& Geiger, V. (2019). Numeracy in adult education: Discussing related concepts to enrich the numeracy assessment framework. In Eleventh Congress of the European Society for Research in Mathematics Education (No. 3). Freudenthal Group; Freudenthal Institute; ERME.

Peters, E. (2012). Beyond comprehension: The role of numeracy in judgments and decisions. Current Directions in Psychological Science, 21, 31-35. https://doi.org/10.1177/0963721411429960

Polat, S. (2014). Türkiye’nin 2023 vizyonu ve eğitimde orta kalite tuzağı. Ankara: SETA.

Reder, S. (2015). Digital inclusion and digital literacy in the US: A portrait from PIAAC's survey of adult skills. Journal of Research and Practice for Adult Literacy, Secondary, and Basic Education, 4(2), 58-63.

Reder, S., \& Bynner, J. (2008). Tracking Adult Literacy and Numeracy Skills: Findings from Longitudinal Research. Routledge. https://doi.org/10.4324/9780203888889

Rehman, M. H., Chang, V., Batool, A., \& Wah, T. Y. (2016). Big data reduction framework for value creation in sustainable enterprises. International Journal of Information Management, 36(6), 917-928. https://doi.org/10.1016/j.ijinfomgt.2016.05.013

Schleicher, A. (2008). PIAAC: A new strategy for assessing adult competencies. International Review of Education, 54(5-6), 627-650. https://doi.org/10.1007/s11159-008-9105-0

Spelke, E. S. (2005). Sex differences in intrinsic aptitude for mathematics and science?: A critical review. American Psychologist, 60(9), 950.

Spitz-Oener, A. (2006). Technical Change, Job Tasks, and Rising Educational Demands: Looking outside the Wage Structure. Journal of Labor Economics, 24(2), 235-270. https://doi.org/10.1086/499972

St. Clair, R. (2016). Plus ça change - The failure of PIAAC to drive evidence-based policy in Canada. Zeitschrift Für Weiterbildungsforschung, 39(2), 225-239. https://doi.org/10.1007/s40955-016-0070-0

Stevens, J. P. (2012). Applied multivariate statistics for the social sciences. Routledge.

Storen, L. A. (2016). Factors that promote innovativeness and being an innovative learner at work - results from PIAAC. European Journal of Education, 51(2), 176-190. https://doi.org/10.1111/ejed.12173

Şaşmazel, A. G. (2006). Uluslararası öğrenci değgerlendirme programı (PISA)'nda Türk ögrencilerin fen bilgisi başarısını etkileyen faktörler (Unpublished master thesis). Ankara. Hacettepe Üniversitesi Eğitim Bilimleri Enstitüsü.

Tabachnick, B. G., \& Fidell, L. S. (2013). Multivariate statistics. Using Multivariate Statistics (6th ed.). Pearson Education, Boston.

TEDMEM. (2016a). OECD yetişkin becerileri araştırması: Türkiye ile ilgili sonuçlar. Ankara: TED.

Tezoh, T. L. (2015). Öğrencilerin matematik okuryazarliği ile bilgi ve iletişim teknolojileri (BIT) erişimi ve kullanimi arasindaki ilişkinin PISA 2012 verisiyle incelenmesi (Unpublished master thesis). İstanbul. Boğaziçi Üniversitesi Fen Biilimleri Enstitüsü .

Toffler, A. (1981). Üçüncü dalga. İstanbul: Altın Kitaplar.

UNESCO. (2005). UN Decade of Education for Sustainable Development 2004-2005. Paris: UNESCO.

UNESCO. (2017). Global education monitoring report 2017/8 - Accountability in education: Meeting our commitments. Paris: UNESCO $\quad$ Publishing. 2017. http://unesdoc.unesco.org/images/0025/002593/259338e.pdf

Wedege, T. (2010). People's mathematics in working life: Why is it invisible? ALM International Journal, 5(1), 89-97.

Yaşar, N. (2018). Eğitimde cinsiyet eşitsizliğinin okullaşma oranına etkisi: Gelişmiş ve gelişmekte olan ülkeler karşılaştırması. Kadın Araştırmaları Dergisi, 17, 55-69.

Yiğit, F. (2013). Sınıf öğrencilerinin anlam bilgisindeki başarı durumlarını etkileyen değişkenlerin incelenmesi: Rize örneği. Ĕgitim ve Öğretim Araştırmaları Dergisi, 2(1), 165-175. 
Yıldırım, A., Hacıhasanoğlu, R., Karakurt, P., \& Türkleş, S. (2011). Lise öğrencilerinin problem çözme becerileri ve etkileyen faktörler. Uluslararası Insan Bilimleri Dergisi, 8(1), 905-921.

Yıldız, A. (2004). Türkiye'deki yetişkin eğitimi araştırmalarına toplu bakış. Ankara Üniversitesi Eğitim Bilimleri Fakültesi Dergisi, 37(1), 78-96. 